\title{
BIOENGINEERED TITANIUM SURFACES AFFECT THE GENE-EXPRESSION AND PHENOTYPIC RESPONSE OF OSTEOPROGENITOR CELLS DERIVED FROM MOUSE CALVARIAL BONES
}

Juliane Isaac ${ }^{1,2,3, *}$, Anouk Galtayries ${ }^{5}$, Takashi Kizuki $^{6}$, Tadashi Kokubo ${ }^{6}$, Ariane Berdal ${ }^{1,2,3,4}$, and Jean-Michel Sautier ${ }^{1,2,3,4}$

${ }^{1}$ INSERM, U872, Eq.5, Laboratoire de Physiopathologie Orale Moléculaire, F-75006 Paris, France

${ }^{2}$ Centre de Recherche des Cordeliers, Université Pierre et Marie Curie, UMR S 872, F-75006 Paris, France

${ }^{3}$ Université Paris Descartes, UMR S 872, F-75006 Paris, France

${ }^{4}$ Université Paris7, UFR d'Odontologie, F-75006 Paris, France

${ }^{5}$ Laboratoire de Physico-Chimie des Surfaces, CNRS ENSCP (UMR 7045), Ecole Nationale Supérieure de Chimie de Paris (Chimie ParisTech), F-75005 Paris, France

${ }^{6}$ Department of Biomedical Sciences, College of Life and Health Sciences, Chubu University, Kasugai, Aichi 4878501, Japan.

\section{Abstract}

This study investigated the in vitro effects of bioactive titanium surfaces on osteoblast differentiation. Three titanium substrates were tested: a commercially pure titanium $(\mathrm{Cp} \mathrm{Ti})$, an alkali- and heat-treated titanium $(\mathrm{AH}$ $\mathrm{Ti}$ ), and an apatite-formed titanium (Ap Ti) generated by soaking $\mathrm{AH}$ Ti in a simulated body fluid. Chemical evaluation of the surface reactivity was analysed at nanometre scale by X-ray photoelectron spectroscopy (XPS), and at micrometre scale by energy dispersive Xray microanalysis (EDX). It showed that the estimated proportion of the surface covered by adsorbed serum proteins differed between the three substrates and confirmed the bioactivity of AH Ti, illustrated by surface calcium and phosphate deposition when immersed in biological fluids. Mouse calvaria osteoblasts were cultured on the substrates for 15 days with no sign of cytotoxicity. Enzyme immunoassay and Real-Time RT-PCR were used to follow osteoblast differentiation through the production of osteocalcin (OC) and expression of several bone markers. At day 15, a significant up-regulation of Runx2, Osx, Dlx5, ALP, BSP, OC and DMP1 mRNA levels associated with an increase of OC production were observed on $\mathrm{AH}$ Ti and Ap Ti when compared to $\mathrm{Cp}$ Ti. These results suggest that bioengineered titanium has a great potential for dental applications in enhancing osseointegration.

Keywords: Biomaterials, biomimetics, surfaces, in vitro, cell/protein-material interactions, osteoblasts, differentiation.

*Address for correspondence:

Juliane Isaac

Laboratoire de Physiopathologie Orale Moléculaire

Centre de Recherche des Cordeliers, INSERM, UMRS 872,

Equipe 5, Esc. E - 2ème étage, 15-21 rue de 1'Ecole de Médecine,

F-75006 Paris, France.

Telephone Number: 33 (0)1. 43.26.94.96

FAX Number: 33 (0)1. 44.07.14.21

E-mail: isaacjuliane@yahoo.fr

\section{Introduction}

Treatment of partial and total edentulism with dental implants has become a reliable procedure for the majority of patients and is expected to play a major role in oral rehabilitation in the future. Studies of the long-term outcomes suggest that many of the implant techniques now consistently lead to their successful integration and therapeutic restoration (Adell et al., 1981; Buser et al., 1997).

Titanium (Ti) and its alloys are used extensively for medical devices in dental, orthopaedic and cardiovascular fields due to their relatively low elastic modulus, high corrosion resistance and excellent biocompatibility (Pohler, 2000). Nevertheless, although surface topography of titanium implants has been shown to modulate the percentage of bone-implant contact and the mechanical strength of bone-implant attachment (Pearce et al., 2008; Hayes et al., 2009), titanium and its alloys are bioinert materials. Indeed, titanium implants do not chemically bond to the bone; rather, they are simply incorporated into a bone contact (Yan et al., 1997).

To provide the metal with bone-bonding ability and thus improve dental implant osseointegration, alternative methods are under investigation. For example, the coating of metallic implants with bioactive materials, such as hydroxyapatite (HA), has become a well-established method. Many techniques including ion beam sputtering, dipping, and electrophoretic or electrochemical deposition are currently being studied for the application of HA coatings to metal substrates; however plasma spray is the most commonly used technique for clinical applications (Sun et al., 2001). However, while many studies report good short-term clinical results with enhanced performance of plasma-sprayed HA-coated implants, clinical studies show that long-term implantation is associated with bone loss and inflammation around many of the HA-coated implants (Albrektsson, 1998). These problems are thought to arise from degradation of the coating, a poor adhesion of the HA coating to the metal surface, the low crystallinity of the apatite and the nonuniformity of the thickness of the deposited apatite layer (Wang et al., 1995; Munting, 1996; Martini et al., 2003).

To overcome these limitations, a biomimetic approach conferring bone-bonding ability to metallic materials has 
been developed (Kim et al., 1996). The surface of the implant is modified by a thermochemical treatment (i.e., alkali- and heat-treatment) to create a layer of functional groups, which induce effective bone-like apatite growth after in vivo implantation of the treated material (Kokubo et al., 2004; Yan et al., 1997). Interestingly, the in vivo apatite formation process can be reproduced in vitro using alkali- and heat-treated titanium soaked in a simulated body fluid (SBF) with ion concentrations nearly equal to human blood plasma (Kokubo and Takadama, 2006).

The use of bone explants and bone cell culture can provide powerful in vitro tools for in-depth studies of the biological mechanisms underlying osteoconduction and de novo bone formation on an endosseous implant surface (Davies, 1996; Cooper et al., 1998). We previously proposed and characterised an in vitro model using foetal calvaria bone explants that mimic in vivo bone formation on endosseous dental implants (Isaac et al., 2009). Using this model of osteoconduction, we showed that alkali-and heat-treated titanium soaked in SBF creates a favourable template for osteoblast migration, differentiation and bone nodule formation. However, only qualitative data can be obtained using this model due to the variable numbers of migrating cells between different explants. A complementary approach is therefore needed to provide quantitative data.

The aim of the present study was to investigate, in a quantitative manner, the in vitro effects of "biomimetic" treatments on titanium surface reactivity and on biological events associated with osteoblast viability and differentiation. Using X-ray photoelectron spectroscopy (XPS) and energy dispersive X-ray microanalysis (EDX), we firstly performed the chemical surface characterisation and then carried out an in vitro study of the physicochemical surface reactivity of alkali- and heattreated titanium (AH Ti) and AH Ti soaked in SBF (Ap $\mathrm{Ti}$ ), with respect to commercially pure titanium (Cp Ti). Secondly, we studied bone cell behaviour on tested surfaces using a primary cell culture system from foetal mouse calvaria that closely mimics the in vivo intramembranous bone formation process, from the stage of osteoprogenitor cell proliferation through to the stages of matrix formation and mineralization.

\section{Materials and methods}

\section{Preparation of the titanium samples Materials}

Standard medical grade commercially pure ( $\mathrm{Ti}>99.5 \%)$ titanium (Cp Ti) samples (Nilaco Co., Tokyo, Japan) 10x10 $\mathrm{mm}^{2}$ with a height of $1 \mathrm{~mm}$ in size were polished with $\mathrm{N}^{\circ}$ 400 diamond plate, and then washed in acetone, 2propanol, and ultra-pure water using an ultrasonic cleaner for 30 minutes each. To produce alkali- and heat-treated titanium (AH Ti), the $\mathrm{Cp}$ Ti was soaked in $5 \mathrm{ml}$ of a $5 \mathrm{M}$ $\mathrm{NaOH}$ solution at $60^{\circ} \mathrm{C}$ for 24 hours and subsequently heattreated at $600^{\circ} \mathrm{C}$ for one hour. Apatite-formed titanium (Ap $\mathrm{Ti}$ ) was generated by soaking the $\mathrm{AH}$ Ti for two days at $36.5^{\circ} \mathrm{C}$ in $24 \mathrm{ml}$ of acellular simulated body fluid (SBF) with ion concentrations nearly equal to human blood plasma (142.0 mM Na+, $5.0 \mathrm{mM} \mathrm{K}+1.5 \mathrm{mM} \mathrm{Mg}^{2+}, 2.5$
$\mathrm{mM} \mathrm{Ca}^{2+}, 147.8 \mathrm{mM} \mathrm{Cl}^{-}, 4.2 \mathrm{mM} \mathrm{HCO}_{3}^{-}, 1.0 \mathrm{mM} \mathrm{HPO}_{4}^{2-}$ and $0.5 \mathrm{mM} \mathrm{SO}_{4}^{2-}$ ). SBF was prepared by dissolving reagent grade chemicals $-\mathrm{NaCl}, \mathrm{NaHCO}_{3}, \mathrm{KCl}$, $\mathrm{K}_{2} \mathrm{PO}_{4} \cdot 3 \mathrm{H}_{2} \mathrm{O}, \mathrm{MgCl}_{2} \cdot 6 \mathrm{H}_{2} \mathrm{O}, \mathrm{CaCl}_{2}$, and $\mathrm{Na}_{2} \mathrm{SO}_{4}-$ into distilled water, buffered at $\mathrm{pH} \quad 7.40$ with trishydroxymethylaminomethane and $1.0 \mathrm{M} \mathrm{HCl}$, at $36.5^{\circ} \mathrm{C}$. Prior to each experiment, the titanium samples were sterilized by dry heat at $180^{\circ} \mathrm{C}$ for $3 \mathrm{~h}$ in a furnace.

\section{Surface Characterisation \\ $X P S$}

Ti-based samples were treated with phosphate buffered saline (PBS), pH 7.4 (Invitrogen, San Diego, CA, USA) by covering the surface with a drop $(100 \mu \mathrm{l})$ of PBS, for 1 $\mathrm{h}$ at $37^{\circ} \mathrm{C}$, in the same atmosphere as used for cell culture (see "Cell culture and analyses" part). Samples were then rinsed three times in PBS for 10 min and dried in ambient air before X-ray photoelectron spectroscopy (XPS) analysis. XPS analysis was performed with the Thermo ESCALAB $250 \mathrm{X}$-ray photoelectron spectrometer, with monochromatised, focused $\mathrm{Al} \mathrm{K} \mathrm{K}_{\alpha}$ source $(\mathrm{hv}=1486.6 \mathrm{eV})$. Base pressure during analysis was about $10^{-9}$ mbar. Survey (wide-scan) spectra were recorded at a pass energy of 100 $\mathrm{eV}$ (low energy resolution spectra). C 1s, Ca 2p, Cl 2p, N $1 \mathrm{~s}, \mathrm{Na} 1 \mathrm{~s}, \mathrm{O} 1 \mathrm{~s}, \mathrm{P} 2 \mathrm{p}$ and Ti $2 \mathrm{p}$ core level spectra were recorded at a pass energy of $20 \mathrm{eV}$ (high energy resolution spectra). All analyses were carried out with a take-off angle of $90^{\circ}$. Each sample was characterised by two different $500 \mu \mathrm{m}$-diameter spot analyses. The spectrometer was calibrated against the reference binding energies (BEs) of clean $\mathrm{Cu}, \mathrm{Ag}$ and $\mathrm{Au}$ samples. When necessary, a flood gun was used at an energy level of $2 \mathrm{eV}$. To take into account the effects of surface charging, high resolution spectra core level BEs were referenced by setting the lowest $\mathrm{BE}$ component of the resolved $\mathrm{C}$ 1s peak (corresponding to carbon in a hydrocarbon environment) to $285.0 \mathrm{eV}$. Data processing was carried out using the commercial Avantage software, provided by Thermo Electron Corporation (Thermo Scientific, Waltham, MA, USA), using a Shirleytype background and Gaussian/Lorentzian peak shapes.

\section{In vitro chemical evaluation of surface reactivity $X P S$}

Ti-based samples were treated with foetal calf serum (FCS, Invitrogen), by covering the surface with a drop $(100 \mu \mathrm{l})$ $10 \%$ FCS solution, diluted in PBS, for $1 \mathrm{~h}$ at $37^{\circ} \mathrm{C}$, in the same atmosphere as used for cell culture (see "Cell culture and analyses" part). Samples were then rinsed three times in PBS for 10 min and dried in ambient air. XPS analysis was performed as described above.

\section{EDX}

Titanium samples were soaked in cell-free culture medium (see "Cell culture and analyses" part) for 0, 3, 7 and 15 days. The samples were then washed with PBS, pH 7.4 (Invitrogen), dried at $37^{\circ} \mathrm{C}$, mounted on specimen stubs and finally sputter-coated with carbon using a Polaron unit (Polaron Equipment, Watford, U.K). Chemical analyses of the samples were performed using a JEOL JSM 6100 scanning electron microscope (SEM) (Jeol France, Croissy-Sur-Seine, France) with a $15 \mathrm{kV}$ accelerating 
voltage connected to an energy dispersive X-ray (EDX) microanalyser (EDX II; Link Analytical, Oxford Instruments, Oxford, U.K.).

Results of surface reactivity analyses are presented in the supporting information.

\section{Cell culture and analyses}

\section{Primary cell cultures}

Osteoblastic cells were enzymatically isolated from calvaria of Swiss OF1 mouse foetuses on embryonic day 18. All procedures for the care and use of animals were conducted after approval from the regional animal experimentation ethics committee (p3/2008/043) and the French Ministry for the Environment and Research (no. 5195). Briefly, frontal and parietal bones of calvaria were aseptically dissected and bone fragments were digested with $0.25 \%$ collagenase type I (Sigma-Aldrich, St. Louis, MO, USA) in PBS for 2 hours at $37^{\circ} \mathrm{C}$. Cells dissociated from bone fragments were then directly plated onto Tibased samples at a density of $2 \times 10^{4}$ cells $/ \mathrm{cm}^{2}$, and grown in osteogenic medium composed of DMEM (Invitrogen) supplemented with 10\% FCS (Invitrogen), $50 \mu \mathrm{g} / \mathrm{mL}$ ascorbic acid (Sigma), $10 \mathrm{mM} \beta$-glycerophosphate (SigmaAldrich), and $50 \mathrm{IU} / \mathrm{mL}$ penicillin-streptomycin (Invitrogen). The cells were maintained at $37^{\circ} \mathrm{C}$ in a fully humidified atmosphere in air with $5 \% \mathrm{CO}_{2}$. Culture medium was changed at 48 -h intervals. For each experiment eight pregnant mice were sacrificed. Averages of eight foetuses were obtained from each animal and then all foetuses were pooled before dissections of the calvaria.

Cell morphology-scanning electron microscopy (SEM) After $24 \mathrm{~h}$ of culture on the various titanium samples, calvarial bone cells were fixed for $1 \mathrm{~h}$ in Karnovsky solution (4\% paraformaldehyde, 1\% glutaraldehyde) and rinsed three times with $0.2 \mathrm{M}$ sodium cacodylate buffer at $\mathrm{pH}$ 7.4. Samples were then dehydrated through a graded series of ethanol and amyl acetate solutions before critical point drying in $\mathrm{CO}_{2}$. Finally, the samples were mounted on specimen stubs and sputter-coated with gold palladium. Samples were examined on a JEOL JSM 6100 scanning electron microscope (Jeol France) with a $15 \mathrm{kV}$ accelerating voltage.

\section{Cell viability-MTS test}

Cell viability at $24 \mathrm{~h}, 72 \mathrm{~h}$ and day 7 was measured using The Cell Titer 96 Aqueous One Solution Cell Proliferation Assay (Promega, Madison, WI, USA). This assay measures formazan production in living cells that are capable of reducing the MTS tetrazolium compound ((3-) (4,5dimethylthiazol-2-yl)-5-(3-carboxymethoxyphenyl)-2-(4sulfophenyl)-2H-tetrazolium), to coloured formazan derivatives. This intracellular bioreduction mostly occurs in the mitochondria. The amount of coloured formazan derivatives excreted into the culture medium can then be measured with a microplate reader. The optical density (OD) of the cell supernatant was measured with a spectrophotometer (Precision Microplate Reader, Molecular Devices, Sunnyvale, CA, USA) at $490 \mathrm{~nm}$. Cells grown on Thermanox Plastic coverslips (NUNC, Rochester, NY, USA) served as a control.
Evaluation of gene expression - real-time reverse transcription-polymerase chain reaction (RT-PCR)

Calvarial bone cells grown on the three different titanium squares were recovered on days 3, 7 and 15 . Total RNA was extracted using the TriReagent kit (Euromedex, Souffelweyersheim, France), following the supplier's instructions. Briefly, total RNA was precipitated with isopropanol and centrifuged at $12000 \mathrm{~g}$ at $4^{\circ} \mathrm{C}$. The RNA pellet was then washed with $75 \%$ ethanol and resuspended in RNase-free water. The concentration and purity of total RNA in each sample were determined by light absorbance at $260 \mathrm{~nm}$ and by calculating the $\mathrm{A}_{260} / \mathrm{A}_{280}$ ratio, respectively. The integrity of RNA was confirmed by electrophoresis on an agarose ethidium bromide gel. For each sample, $1 \mu \mathrm{g}$ of total RNA was reverse transcribed into cDNA using 200 units of Superscript II (Invitrogen) and $250 \mathrm{ng}$ of random primers, according to the manufacturer's instructions. Real-time PCR was performed using a MiniOpticon Real-Time PCR Detection System (Bio-Rad Laboratory, Hercules, CA, USA). As recommended by the manufacturer, we used a reaction volume of $15 \mu \mathrm{l}$ containing $7.5 \mu \mathrm{l}$ of IQ SYBR Green Supermix (Bio-Rad), $50 \mathrm{ng}$ of cDNA as template and 0.3 $\mu \mathrm{M}$ of the appropriate primer-pairs (see Table 1) (Eurogentec, Liège, Belgium). The final mixture was incubated in the MiniOpticon under the following conditions: $98^{\circ} \mathrm{C}$ for $10 \mathrm{sec}$ (denaturation), followed by 40 amplification cycles of $95^{\circ} \mathrm{C}$ for $10 \mathrm{sec}, 60^{\circ} \mathrm{C}$ for 20 sec, and $72^{\circ} \mathrm{C}$ for $20 \mathrm{sec}$. We checked for specificity by ensuring that each transcript tested was represented by a single peak in the melting curve.

Each target cDNA amplification was run in triplicate on a single 48-well plate. Samples representative of all treatments were included, as were no-template controls and five dilutions (1/10-1/810) of a control cDNA sample. The amplification curve of the target gene was created using these various dilutions to estimate gene expression of each sample. Gene expression levels were normalised to the expression of the housekeeping gene GAPDH. Results were expressed as fold changes relative to the expression levels in cells grown on commercially pure titanium samples (Cp Ti) at day 3 .

\section{Osteocalcin protein production}

Osteocalcin (OC) protein levels in cell culture supernatants were determined by an enzyme immunoassay (EIA) kit for intact mouse OC (Biomedical Technologies, Stoughton, MA, USA). Cells were cultured on the various titanium samples for 3, 7 and 15 days. Culture medium was replaced by serum-free medium $48 \mathrm{~h}$ prior to assaying. Culture medium was replaced by serum-free medium $48 \mathrm{~h}$ before assaying. Supernatants were collected and assayed according to the manufacturer's instructions and OC protein levels were normalised to total cell number.

\section{Statistical analysis}

All experiments were repeated three times using independent primary cell cultures, with the measurements for each biomarker at each time point performed in triplicate. Data from these three independent experiments have been pooled for statistical computations and 
Table 1. Primers used in real-time quantification of selected gene transcripts.

\begin{tabular}{|c|c|c|c|}
\hline Gene transcript & Code & Forward primer sequence & Reverse primer sequence \\
\hline GAPDH & $\begin{array}{l}\text { XM_001 } \\
473623.1\end{array}$ & АССССТТСАТTGACСТCAACTAC & AGTTGTCATGGATGACCTTG \\
\hline $\begin{array}{l}\text { Msx2 } \\
\text { (Homeobox, } \\
\text { msh-like 2) }\end{array}$ & $\begin{array}{c}\text { NM_013 } \\
601.2\end{array}$ & CCTGAGGAAACACAAGACCA & AGTTGATAGGGAAGGGCAGA \\
\hline $\begin{array}{l}\text { Dlx5 } \\
\text { (Distal-less } \\
\text { homeobox 5) }\end{array}$ & $\begin{array}{c}\text { NM_198 } \\
854.1\end{array}$ & CTGGCCGCTTTACAGAGAAG & CTGGTGACTGTGGCGAGTTA \\
\hline $\begin{array}{l}\text { Runx2 } \\
\text { (Runt related } \\
\text { transcription } \\
\text { factor 2) }\end{array}$ & $\begin{array}{c}\text { NM_009 } \\
820.2\end{array}$ & GGACGAGGCAAGAGTTTCAC & TGCCTGCCTGGGATCTGTAA \\
\hline $\begin{array}{l}\text { Osterix } \\
\text { (Trans-acting } \\
\text { transcription } \\
\text { factor 7) }\end{array}$ & $\begin{array}{c}\text { NM_130 } \\
458.2\end{array}$ & CCTAGGTTATCTCCTTGCATGTCT & ATTGGGAAGCAGAAAGATTAGATG \\
\hline $\begin{array}{l}\text { RP59 } \\
\text { (Hemogen) }\end{array}$ & $\begin{array}{c}\text { NM_053 } \\
149.2\end{array}$ & GGGAACTCTGCAACTGAAGC & GCTATTCCTTGGCATGTGGT \\
\hline $\begin{array}{l}\text { Collagen I } \\
\text { (Collagen, type } \\
\text { I, alpha 1) }\end{array}$ & $\begin{array}{c}\text { NM_007 } \\
742.3\end{array}$ & AAGATGTGCCACTCTGACTG & ATAGGTGATGTTCTGGGAGG \\
\hline $\begin{array}{l}\text { ALP } \\
\text { (Alkaline } \\
\text { phosphatase) }\end{array}$ & $\begin{array}{c}\mathrm{NM}_{4} 007 \\
431\end{array}$ & CCAGCAGGTTTCTCTCTTGG & CTGGGAGTCTCATCCTGAGC \\
\hline $\begin{array}{l}\text { OP } \\
\text { (Osteopontin) }\end{array}$ & $\begin{array}{c}\text { NM_009 } \\
263.1\end{array}$ & ATTTGCTTTTGCCTGTTTGG & CTCCATCGTCATCATCATCG \\
\hline $\begin{array}{l}\text { BSP } \\
\text { (Integrin } \\
\text { binding } \\
\text { sialoprotein) }\end{array}$ & $\begin{array}{c}\text { NM_008 } \\
318.1\end{array}$ & CTTACCGAGCTTATGAGGATGAATA & AAATGGTAGCCAGATGATAAGACAG \\
\hline $\begin{array}{l}\text { Osteocalcin } \\
\text { (BGLAP) }\end{array}$ & $\begin{array}{c}\text { NM_031 } \\
368.3\end{array}$ & CTTGGTGCACACCTAGCAGA & ACCTTATTGCCCTCCTGCTT \\
\hline $\begin{array}{l}\text { DMP1 } \\
\text { (Dentin matrix } \\
\text { protein 1) }\end{array}$ & $\begin{array}{c}\text { NM_016 } \\
779.2\end{array}$ & CAGTGAGGATGAGGCAGACA & TCGATCGCTCCTGGTACTCT \\
\hline
\end{tabular}

expressed as the mean \pm standard error of the mean $(\mathrm{M} \pm$ SEM) for graph representations. Means for biomarkers were compared within the three groups of Ti-based samples, except for the MTS test, in which control data were also included. All statistical computations were performed with the Mann-Whitney test using Prism 4 statistical software (GraphPad Software Inc., San Diego, CA, USA). A $p$ value of less than 0.05 was considered statistically significant.

\section{Results}

\section{Surface chemical characterisation}

Fig. 1a shows the XPS survey spectra for $\mathrm{Cp}$ Ti. The core levels of Ti (Ti 2s, Ti 2p, Ti 3s, Ti 3p), as well as the O 1s core level (characteristic of the presence of oxides), and the core level peaks of surface contaminants, such as C $1 \mathrm{~s}, \mathrm{P} 2 \mathrm{p}$ and $\mathrm{P} 2 \mathrm{~s}, \mathrm{Cl} 2 \mathrm{p}$ and $\mathrm{Cl} 2 \mathrm{~s}, \mathrm{~K} 2 \mathrm{p}$ and $\mathrm{K} 2 \mathrm{~s}$, and $\mathrm{Na}$ $1 \mathrm{~s}$, were observed. Note that there was no signal corresponding to the presence of $\mathrm{Ca}$ on the surface (also checked at higher resolution). $\mathrm{P}, \mathrm{Cl}, \mathrm{K}$ and $\mathrm{Na}$ were most probably contaminants from PBS buffer. As element of comparison, the survey spectrum of the untreated $\mathrm{Cp} \mathrm{Ti}$ surface (sterilised sample only) showed the absence of $\mathrm{P}$, $\mathrm{Cl}, \mathrm{K}$ and $\mathrm{Na}$ as well as less attenuated $\mathrm{O}$ 1s and Ti 2p core level signals (Fig. 1a). The survey spectra for AH Ti samples showed the same core level peaks (data not shown), with the exception of a low intensity signal corresponding to $\mathrm{Ca}$, most probably associated with contamination from prior alkali treatment. The $\mathrm{Ca} / \mathrm{P}$ atomic ratio, calculated from the $\mathrm{Ca} 2 \mathrm{p}$ and $\mathrm{P} 2 \mathrm{p}$ core level intensities, recorded at high energy resolution (pass energy of $20 \mathrm{eV}$ ), was $0.16 \pm 0.03$, which excludes the presence 
a

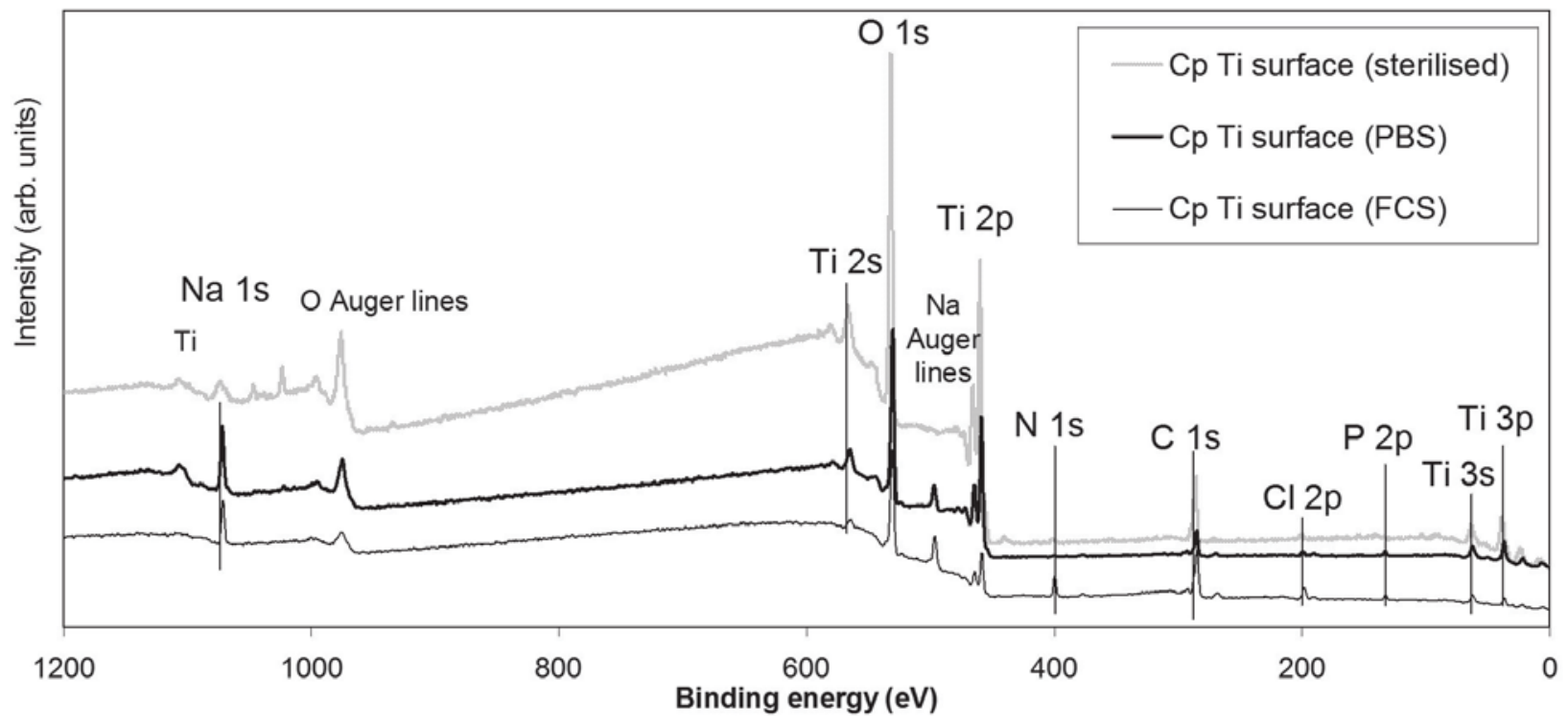

b

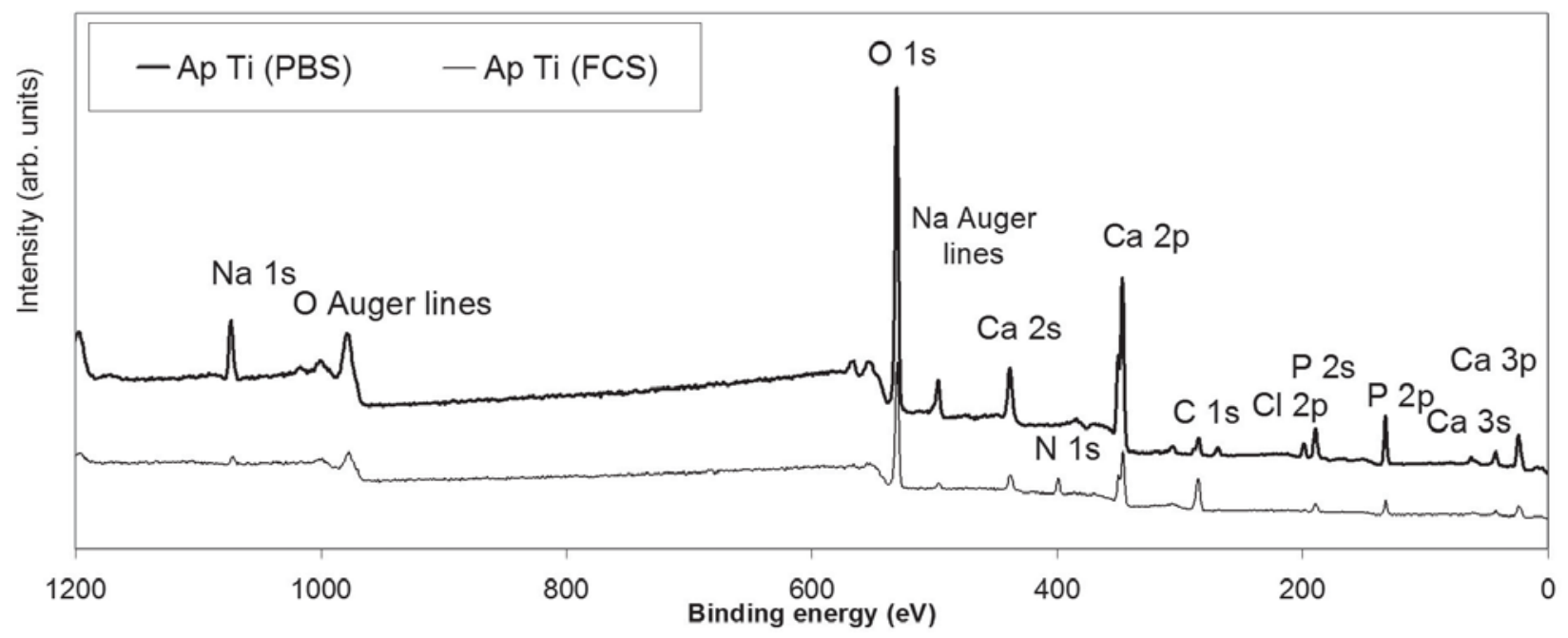

Fig. 1. XPS survey spectra of Cp Ti (a) and Ap Ti (b) before (PBS) and after 1 hour of interaction with foetal calf serum (FCS) at $\mathrm{pH} 7.4,37^{\circ} \mathrm{C}$. The survey spectrum of the sterilised $\mathrm{Cp}$ Ti sample without PBS treatment is also presented in (a).

of stoichiometric apatite on the AH Ti surface. The Na 1s core level signal corresponds both to the interaction of $\mathrm{NaOH}$ (alkali treatment) and PBS buffer.

At higher resolution, the Ti $2 \mathrm{p}$ core level spectra of $\mathrm{Cp}$ Ti surface displayed a small shoulder at lower BEs, characteristic of metallic $\mathrm{Ti}$, in addition to a main contribution, located at about $459 \mathrm{eV}$ (Fig. 2a). The more intense signal at $459 \mathrm{eV}$ corresponds to $\mathrm{Ti}^{4+}$, characteristic of the passive layer formed on Ti surfaces. In order to determine the thickness of the passive layer in $\mathrm{Cp} \mathrm{Ti}$, the Ti $2 p$ core level spectra were systematically decomposed into up to four contributions (i.e., 8 spectral features, including the spectroscopic spin-orbit coupling Ti $2 \mathrm{p}_{3 / 2}-\mathrm{Ti}$ $2 \mathrm{p}_{1 / 2}$, with an energy splitting of $5.7 \pm 0.3 \mathrm{eV}$ between $\mathrm{Ti}$ $2 \mathrm{p}_{1 / 2}$ and Ti $\left.2_{3 / 2}\right)$ at BEs of $454.2 \pm 0.2 \mathrm{eV}\left(\mathrm{Ti} 2 \mathrm{p}_{3 / 2}\right.$ metallic $\mathrm{Ti}), 455.6 \pm 0.1\left(\mathrm{Ti} 2 \mathrm{p}_{3 / 2}, \mathrm{Ti}^{2+}\right), 457.8 \pm 0.1\left(\mathrm{Ti} 2 \mathrm{p}_{3 / 2}, \mathrm{Ti}^{3+}\right)$ and $459.1 \pm 0.1\left(\mathrm{Ti} 2 \mathrm{p}_{3 / 2}, \mathrm{Ti}^{4+}\right)$ (Fig. 2a). For Cp Ti surface, we assumed that $\mathrm{Ti}^{4+}$ corresponds to $\mathrm{TiO}_{2}$, in agreement with published data (see for example (Burgos-Asperilla et al., 2010) (surface characterisations) and (Kim et al., 1999) (bulk data)). From the Ti $2 \mathrm{p}$ decomposition, we calculated the $\mathrm{TiO}_{2}$ layer thickness, assuming a layer model in which $\mathrm{TiO}_{2}$ lies over the Ti surface, using the $\mathrm{I}_{\mathrm{Ti}}^{\mathrm{Ti}_{2}} / \mathrm{I}_{\mathrm{Ti}}^{\text {metal }}$ ratio, where $\mathrm{I}_{\mathrm{Ti}}^{\mathrm{Ti}} \mathrm{O}_{2}$ corresponds to the $\mathrm{Ti} 2 \mathrm{p}_{3 / 2}$ peak intensity of $\mathrm{Ti}^{4+}$ in $\mathrm{TiO}_{2}$ and $\mathrm{I}_{\mathrm{Ti}}^{\text {metal }}$, to the $\mathrm{Ti} 2 \mathrm{p}_{3 / 2}$ peak intensity of metallic Ti. The intensities of the titanium suboxides, located at the metal-TiO interface, were not taken into account for this calculation $\left(<0.2 \times I_{T i}^{\mathrm{TiO}_{2}}\right)$. The resulting thickness of the passive layer on Cp Ti surface was $7.9 \pm 0.1 \mathrm{~nm}$. This value was similar to thickness of the passive layer calculated on the untreated $\mathrm{Cp}$ Ti sample (sterilised only) (data not shown). Thus, as expected for a passivated material, the interaction with PBS in our conditions does not induce titanium oxide growth. 

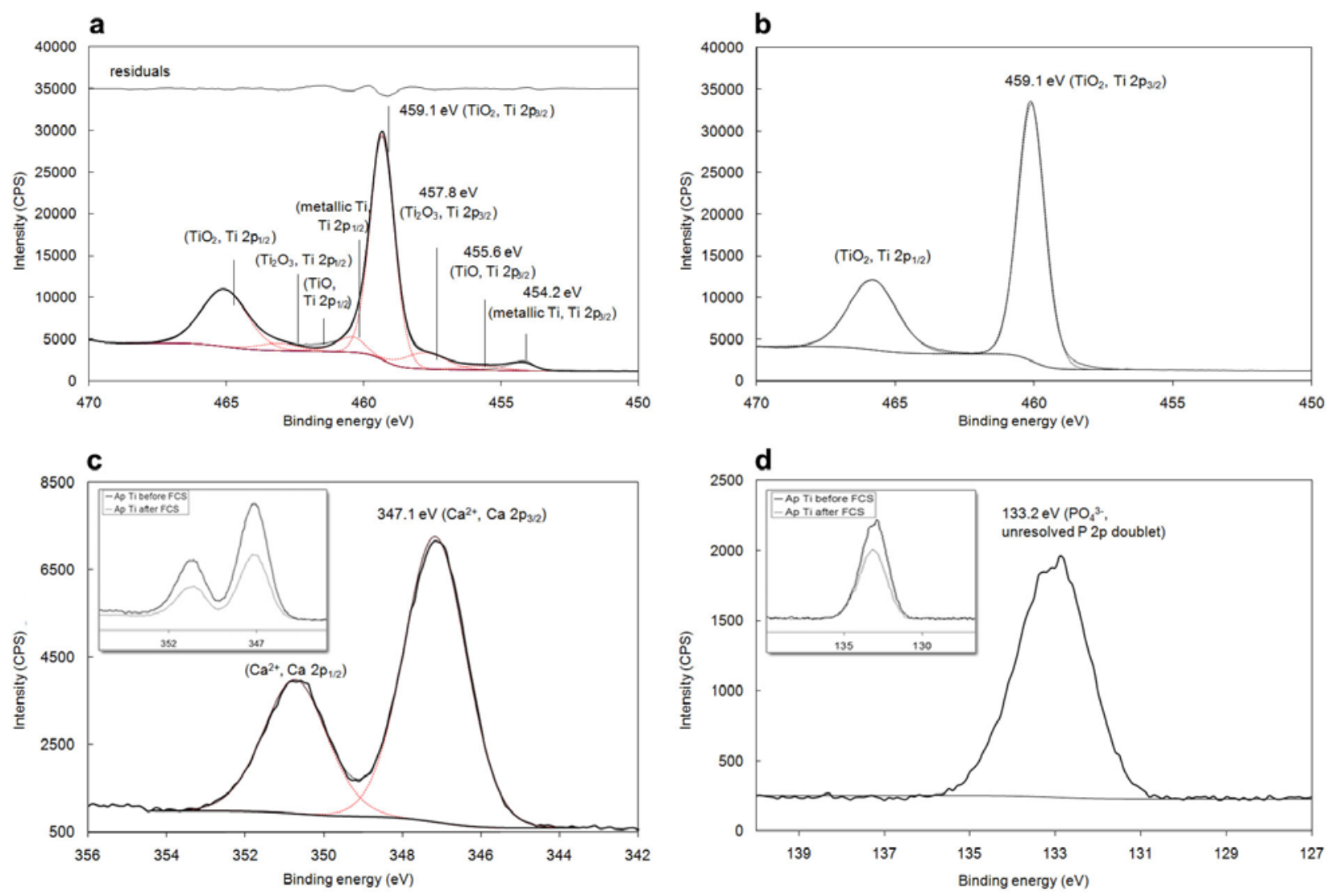

Fig. 2. XPS Ti $2 p$ core level spectra for Cp Ti (a) and AH Ti (b), before interaction with FCS. The Ti $2 p$ core level spectrum (a) is decomposed into individual contributions (in red) corresponding to $\mathrm{TiO}_{2}, \mathrm{Ti}_{2} \mathrm{O}_{3}, \mathrm{TiO}$ and metallic Ti (see text). The residuals (difference between experimental and composed spectra) are plotted in the upper part of the figure. XPS Ca 2p (c) and P 2p (d) core level spectra for Ap Ti, before interaction with FCS. Note: The core level regions of $\mathrm{Ca} 2 \mathrm{p}$ and $\mathrm{P} 2 \mathrm{p}$ for $\mathrm{Ap} \mathrm{Ti}$, before and after interaction with FCS are presented on the left corner of the spectra (c) and (d).
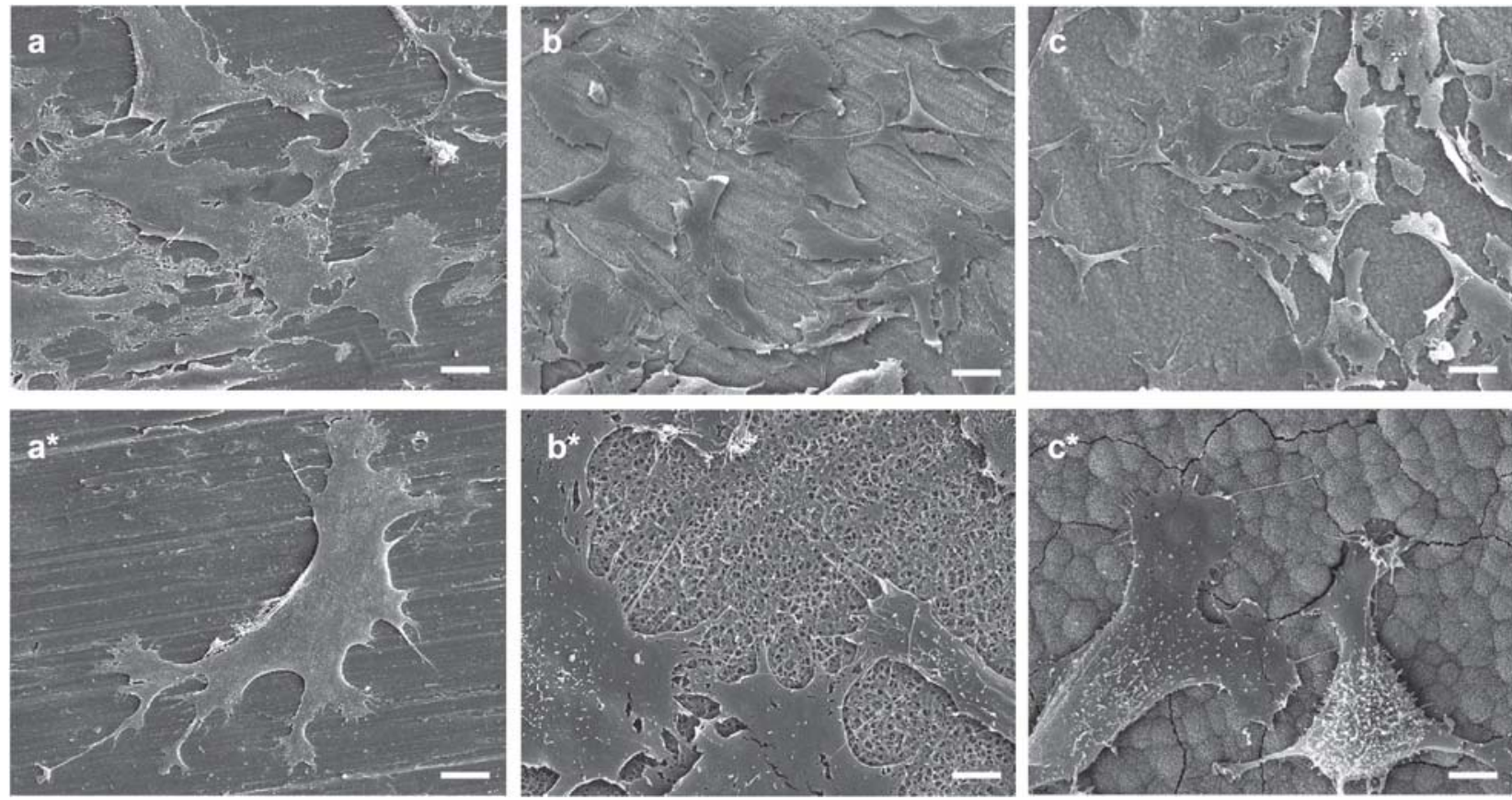

Fig. 3. SEM observations of osteoblastic cells cultured for 24 hours on $\mathrm{Cp}$ Ti (a,a*), AH Ti (b,b*), Ap Ti (c,c*) surfaces. Low magnification micrographs (insulating): Adhering cells cover part of the titanium surfaces and exhibit numerous cell contacts $(\mathrm{Bar}=30 \mu \mathrm{m})$. Higher magnification micrographs $\left(\mathbf{a}^{*}-\mathbf{c}^{*}\right)$ : Cells exhibit numerous ruffles on their dorsal surface and adhere to the titanium surfaces by means of numerous filopodia and lamellipodia $($ Bar $=5$ $\mu \mathrm{m})$. 


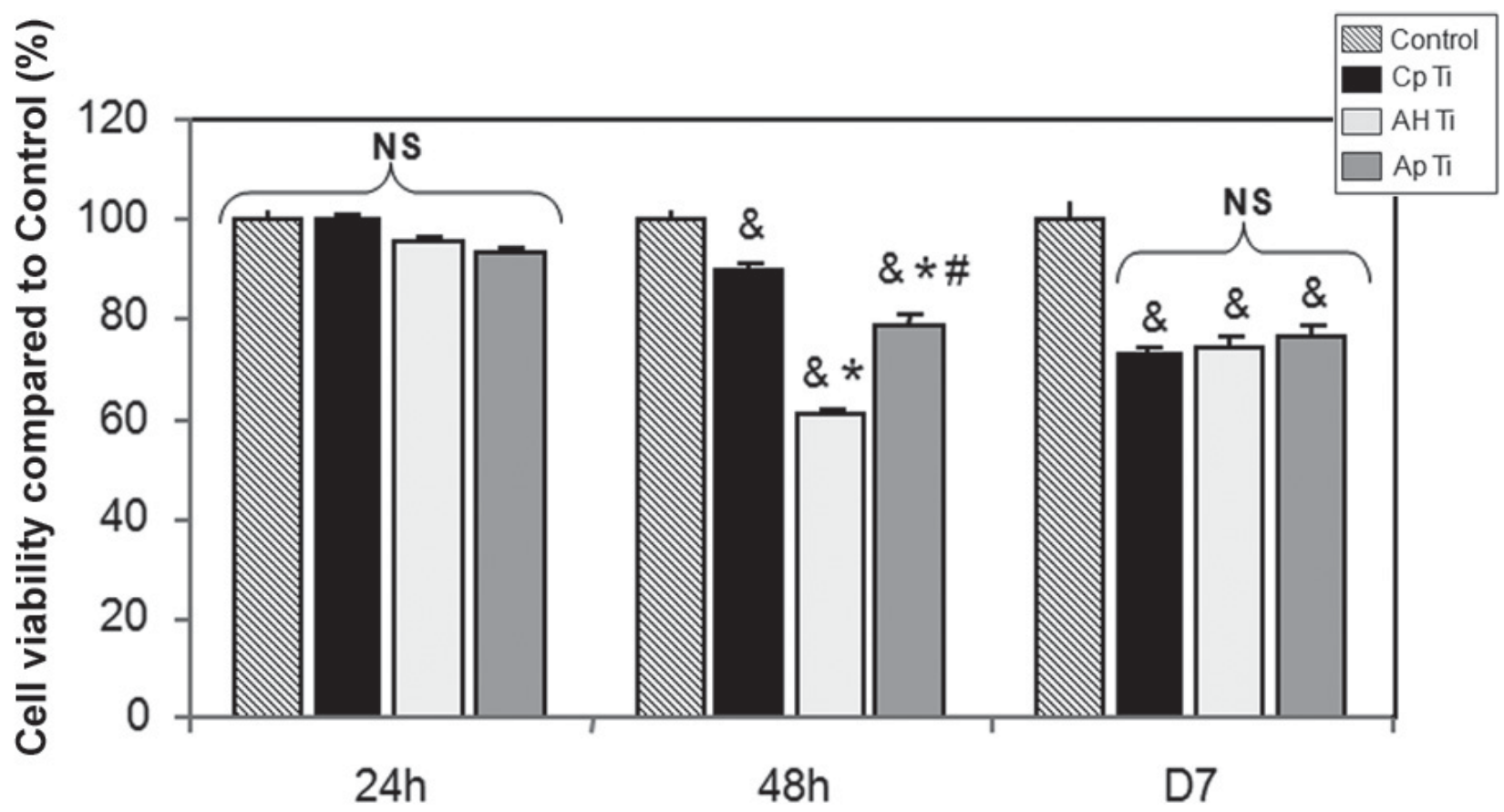

Fig. 4. MTS assay of osteoblastic cells grown on the different substrates at 24 hours, 48 hours and day 7. Measurements for controls (Thermanox Plastic coverslip) were set at 100\% at each time point. Data are expressed in percentages, relative to controls. Statistical analyses were performed using the Mann-Whitney test $(\& p<0.05$ indicates a significant difference, compared with cells grown on the control surfaces; $* p<0.05$ indicates a significant difference, compared with $\mathrm{Cp}$ Ti; and \# $p<0.05$ indicates a significant difference, compared with AH Ti. NS, no significant difference).

Fig. $2 \mathrm{~b}$ shows the Ti $2 \mathrm{p}$ core level spectra of $\mathrm{AH} \mathrm{Ti}$ surface. AH Ti spectra displayed one main peak, at about $459 \mathrm{eV}$, characteristic of $\mathrm{Ti}^{4+}$. The absence of metallic contribution in AH Ti surface indicated that the thickness of the Ti oxide layer was greater than $10 \mathrm{~nm}$ (which is the limit of XPS probing depth). This result was in agreement with previous data obtained by Auger Electron Spectroscopy (AES) (Kim et al., 1999). Indeed, Kim et al. (1999) reported that the untreated sample (Cp Ti) had an ultra-thin $\mathrm{TiO}_{2}$ layer and $\mathrm{AH}$ samples were covered by a crystalline mixed sodium titanate and $\mathrm{TiO}_{2}$ layer, thicker than $500 \mathrm{~nm}$. Thus, we assumed that, in the case of AH Ti, the $\mathrm{Ti} 2 \mathrm{p}$ core level signal corresponds to $\mathrm{Ti}^{4+}$ both from $\mathrm{TiO}_{2}$ and from sodium titanate, identified as $\mathrm{Na}_{2} \mathrm{Ti}_{5} \mathrm{O}_{11}$ by Kim et al. (Kim et al., 1999) or as $\mathrm{Na}_{2} \mathrm{TiO}_{3}$ by Chu et al. (Chu et al., 2005)). The Na/Ti ratio for AH Ti surface, calculated from the $\mathrm{Na} 1 \mathrm{~s}$ and $\mathrm{Ti} 2 \mathrm{p}\left(\mathrm{Ti}^{4+}\right)$ core level intensities, was $0.90 \pm 0.15$. Unfortunately, it was impossible to propose a sodium titanate formula, because this ratio included the $\mathrm{Ti}^{4+}$ contribution from $\mathrm{TiO}_{2}$ and the $\mathrm{Na}$ contamination from PBS (as an illustration, the $\mathrm{Na} / \mathrm{Ti}$ ratio for $\mathrm{Cp}$ Ti surface was $0.60 \pm 0.10$ ). Thus, from a chemical point of view, $\mathrm{AH}$ Ti and $\mathrm{Cp}$ Ti presented many similarities: a $\mathrm{Ti}^{4+}$ and $\mathrm{Na}^{+}$-rich surface, the latter being embedded in a crystalline titanate compound for $\mathrm{AH} \mathrm{Ti}$ and being only randomly adsorbed in a two-dimensional structure for $\mathrm{Cp}$ Ti.

Fig. $1 \mathrm{~b}$ shows the XPS survey spectra of Ap Ti. The most striking difference between $\mathrm{Ap} \mathrm{Ti}$ and both $\mathrm{Cp} \mathrm{Ti}$ (Fig. 1a) and AH Ti (not shown) survey spectra was the absence of any signal characteristic of $\mathrm{Ti}$, indicating that the Ca-P inorganic layer is thicker than $10 \mathrm{~nm}$ on the Ap
Ti surface. Indeed, Kim et al. showed by AES depth profiles that the Ap Ti surfaces were covered by more than $1 \mu \mathrm{m}$ of crystalline apatite (Kim et al., 1999). The expected core levels of Ca (Ca 2s, Ca 2p, Ca 3s, Ca 3p) and P (P 2s, $\mathrm{P} 2 \mathrm{p}$ ), as well as those of $\mathrm{O} 1 \mathrm{~s}$ (characteristic of the presence of oxides) and the characteristic core level peaks of surface contaminants, such as $\mathrm{C} 1 \mathrm{~s}, \mathrm{Cl} 2 \mathrm{p}$ and $\mathrm{Cl} 2 \mathrm{~s}$, and $\mathrm{Na} 1 \mathrm{~s}$, were identified on $\mathrm{Ap} \mathrm{Ti}$ surfaces. $\mathrm{Cl}$ and $\mathrm{Na}$ were most probably contaminants from the PBS buffer, with $\mathrm{P}$ probably coming from both the PBS buffer and the SBF treatment forming the apatite layer on Ap Ti surface (see "Preparation of the titanium samples").

At higher resolution, the $\mathrm{Ca} 2 \mathrm{p}$ core level spectra of Ap Ti surface showed a spectroscopic doublet (Ca 2 $\mathrm{p}_{3 / 2}$ $\left.\mathrm{Ca} 2 \mathrm{p}_{1 / 2}\right)$ at $347.1 \pm 0.2 \mathrm{eV}\left(\mathrm{Ca} 2 \mathrm{p}_{3 / 2}\right)$, characteristic of $\mathrm{Ca}^{2+}$ (Burgos-Asperilla et al., 2010; Ferraz et al., 1999) (Fig. 2c). The P $2 \mathrm{p}$ core level peaks had an unresolved doublet at $133.2 \pm 0.2 \mathrm{eV}$ (Fig. 2d), characteristic of adsorbed $\mathrm{PO}_{4}{ }^{3-}$ (Burgos-Asperilla et al., 2010). The $\mathrm{Ca} / \mathrm{P}$ surface atomic ratio for Ap Ti was determined from the $\mathrm{Ca} 2 \mathrm{p}$ and $\mathrm{P} 2 \mathrm{p}$ core level intensities, giving a ratio of 1.45 \pm 0.25 . This value is in very good agreement with the atomic ratio obtained from $\operatorname{EDX}(1.50 \pm 0.30$, Table S1). Taken together these results suggest that the composition of the Ap Ti outermost $10 \mathrm{~nm}$ (XPS), as well as in its deeper layers (EDX), could be compatible with stoichiometric apatite $\left(\mathrm{Ca}_{5}\left(\mathrm{PO}_{4}\right)_{3} \mathrm{OH}\right) \mathrm{Ca} / \mathrm{P}$ theoretical value of 1.67 . A slightly lower experimental value has already been reported (Lakstein et al., 2009; Lu et al., 2000); in these cases, XPS $\mathrm{Ca} / \mathrm{P}$ atomic ratios of different calcium phosphate phases were consistently lower than the theoretical values. In our case, the small discrepancy could also be attributed to the 

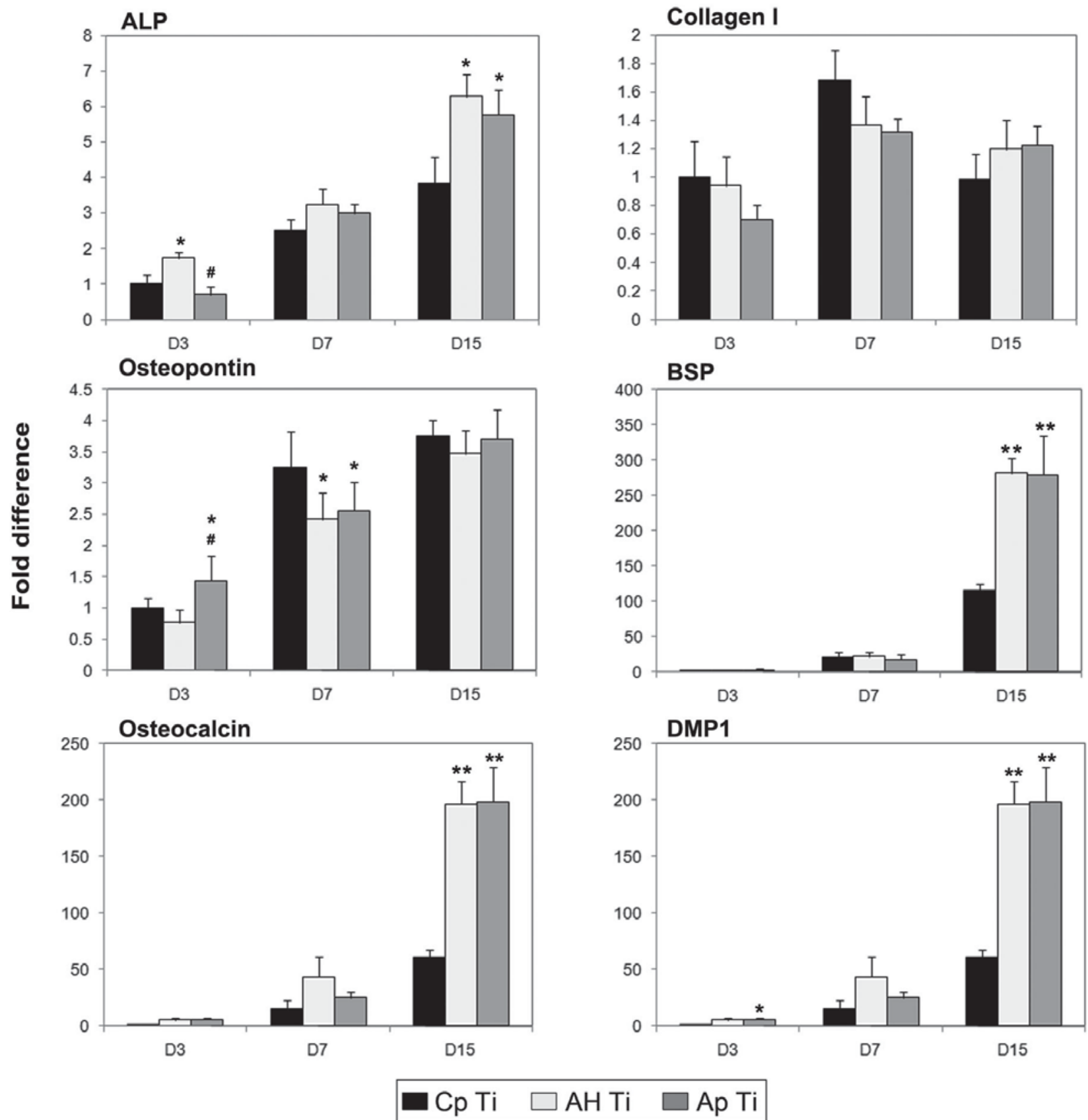

Fig. 5. Real-time PCR analysis of the gene expression for selected bone protein markers on days 3,7 and 15 , in calvarial bone cells cultured on the different substrates: $\mathrm{Cp} \mathrm{Ti,} \mathrm{AH} \mathrm{Ti} \mathrm{and} \mathrm{Ap} \mathrm{Ti.} \mathrm{mRNA} \mathrm{levels} \mathrm{of} \mathrm{the} \mathrm{genes} \mathrm{of}$ interest have been normalised to expression levels of the housekeeping gene GAPDH and are represented as fold difference, relative to $\mathrm{Cp}$ Ti on day 3 . At the same time point, ${ }^{*} p<0.05$ and $* * p<0.01$ indicate a significant difference, compared with cells grown on $\mathrm{Cp}$ Ti; and $\# p<0.05$ indicates a significant difference, compared with cells grown on AH Ti.

presence of adsorbed phosphate (contributing at the same binding energy), resulting from interaction with the PBS buffer.

\section{Cell attachment and spreading}

SEM observations after one day of culture showed that a large part of the titanium surface was covered by a subconfluent cell layer on each tested substrate (Fig. 3ac). Cells were flattened, did not show any specific orientation and had developed an extensive network of intercellular contacts. Higher magnification micrographs revealed that cells anchored to each titanium surface by means of thin cytoplasmic digitations, such as filopodia, or larger digitations, such as lamellipodia (Fig. 3a*-c*). However, in contrast to $\mathrm{Cp}$ Ti surfaces, on which osteoblastic cells had smooth cellular surfaces (Fig.3a*), cells cultured on both AH Ti and Ap Ti surfaces had numerous microvilli and ruffles on their dorsal surfaces (Fig. 3b*-c*).

\section{Cell viability}

Cell viability and metabolic activity were evaluated using the MTS assay. Foetal calvarial cells were cultured on Cp Ti, AH Ti and Ap Ti surfaces and MTS conversion was 

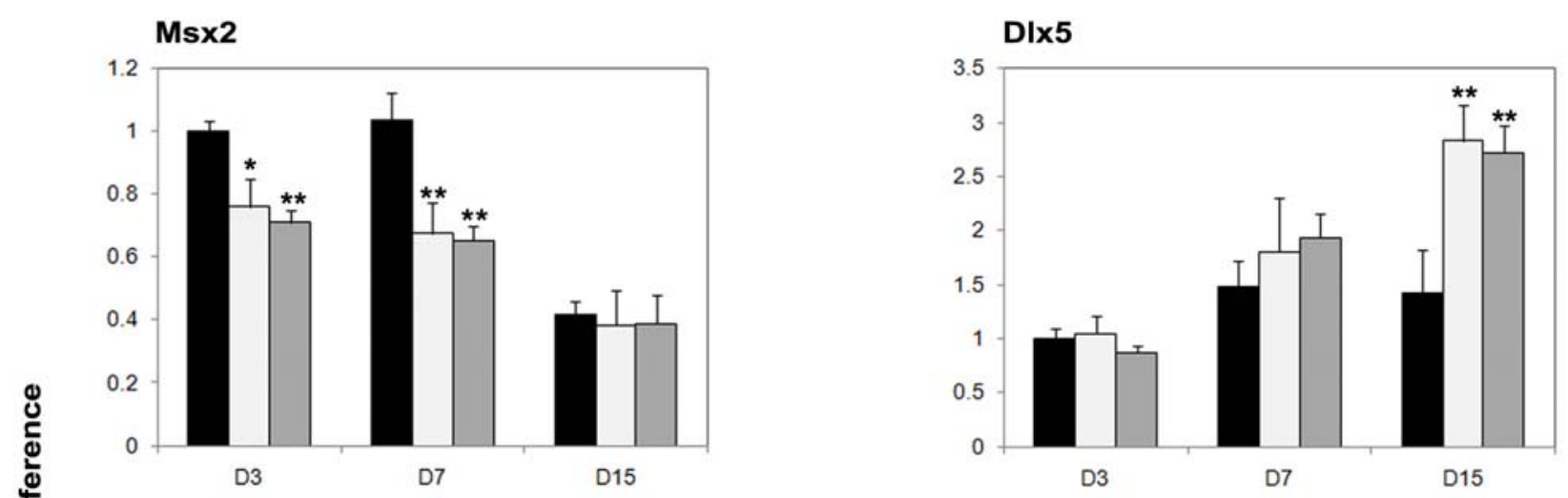

\section{Runx2}

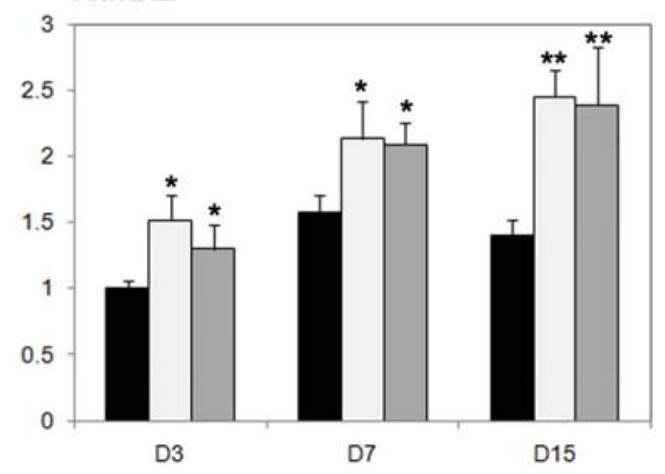

Osterix

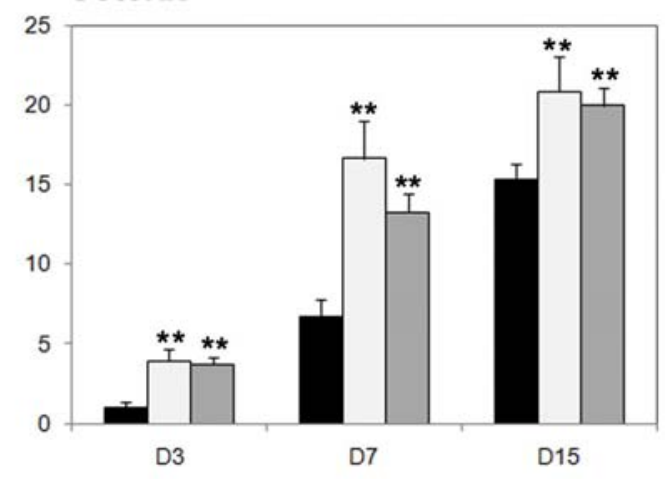

- Cp Ti $\square \mathrm{AHTi} \quad \square \mathrm{ApTi}$

Fig. 6. Real-time PCR analysis of the expression of genes encoding selected osteoblastic transcription factors on days 3, 7 and 15 in foetal calvarial cells cultured on different substrates: Cp Ti, AH Ti and Ap Ti. mRNA levels of the genes of interest have been normalised to expression levels of the housekeeping gene GAPDH and are represented as fold difference relative to $\mathrm{Cp}$ Ti on day 3 . At the same time point, ${ }^{*} p<0.05$ and $* * p<0.01$ indicate a significant difference, compared with cells grown on $\mathrm{Cp}$ Ti; and \# $p<0.05$ indicates a significant difference, compared with cells grown on AH Ti.

assessed after 24 hours, 48 hours and 7 days of culture (Fig. 4). Thermanox plastic coverslips were used as noncytotoxic control surfaces. After 24 hours of culture, no significant differences in cell viability were observed between any of the three titanium surfaces tested and controls. After $48 \mathrm{~h}$ and on day 7 , cell viability on all titanium surfaces - $\mathrm{Cp} \mathrm{Ti,} \mathrm{AH} \mathrm{Ti} \mathrm{and} \mathrm{Ap} \mathrm{Ti} \mathrm{-} \mathrm{was}$ significantly lower than that on control surfaces. After 48 hours, cells that had grown on AH Ti surfaces showed the lowest MTS activity levels, reaching $61.4 \%$ of control values, whereas cell viability on Ap Ti and Cp Ti surfaces was higher, reaching $79 \%$ and $90.2 \%$ of control values, respectively. However, after 7 days, cell viability was similar for all three surfaces, reaching approximately $75 \%$ of control values.

\section{Osteoblast differentiation}

To investigate the effects of various titanium surfaces on osteoblastic differentiation of calvarial bone cells, gene expression levels for selected osteoblast markers, including bone protein markers (Fig. 5), osteoblastic transcription factors (Fig. 6) and the protein RP59 (Fig. 7), were determined using real-time RT-PCR on days 3, 7 and 15. All selected genes were expressed throughout the culture period but showed different expression patterns over time for the different surfaces.
The alkaline phosphatase (ALP) gene expression profile showed a gradual and significant increase in expression levels over the culture period for all titanium surfaces tested $(p<0.01)$ (Fig. 5). However, cells cultured on the AH Ti and Ap Ti surfaces showed a significantly higher ALP mRNA levels on day 15 than cells on Cp Ti surfaces.

Collagen, type I, alpha 1 (collagen I) mRNA levels for both $\mathrm{Cp}$ Ti and Ap Ti surfaces significantly increased up to day $7(p<0.05)$ and then decreased at day $15(p<0.05)$ (Fig. 5). However, for AH Ti surfaces, collagen I mRNA levels remained stable throughout the culture period (NS). Moreover, we did not find any significant differences between the three different surfaces at each time point.

Osteopontin (OP) gene expression levels showed a gradual and significant increase over time, up to day 15 , for all three surfaces $(p<0.01)$ (Fig. 5). On day 7, OP mRNA levels were significantly lower for both $\mathrm{AH}$ Ti and Ap Ti surfaces than for $\mathrm{Cp}$ Ti. However, we did not find any significant differences between the three different surfaces on day 15.

The extracellular bone matrix protein-related genes encoding integrin binding sialoprotein (BSP), osteocalcin (OC) and dentin matrix protein 1 (DMP1) showed similar expression patterns for all surfaces, with low gene expression levels observed on day 3 , followed by a 

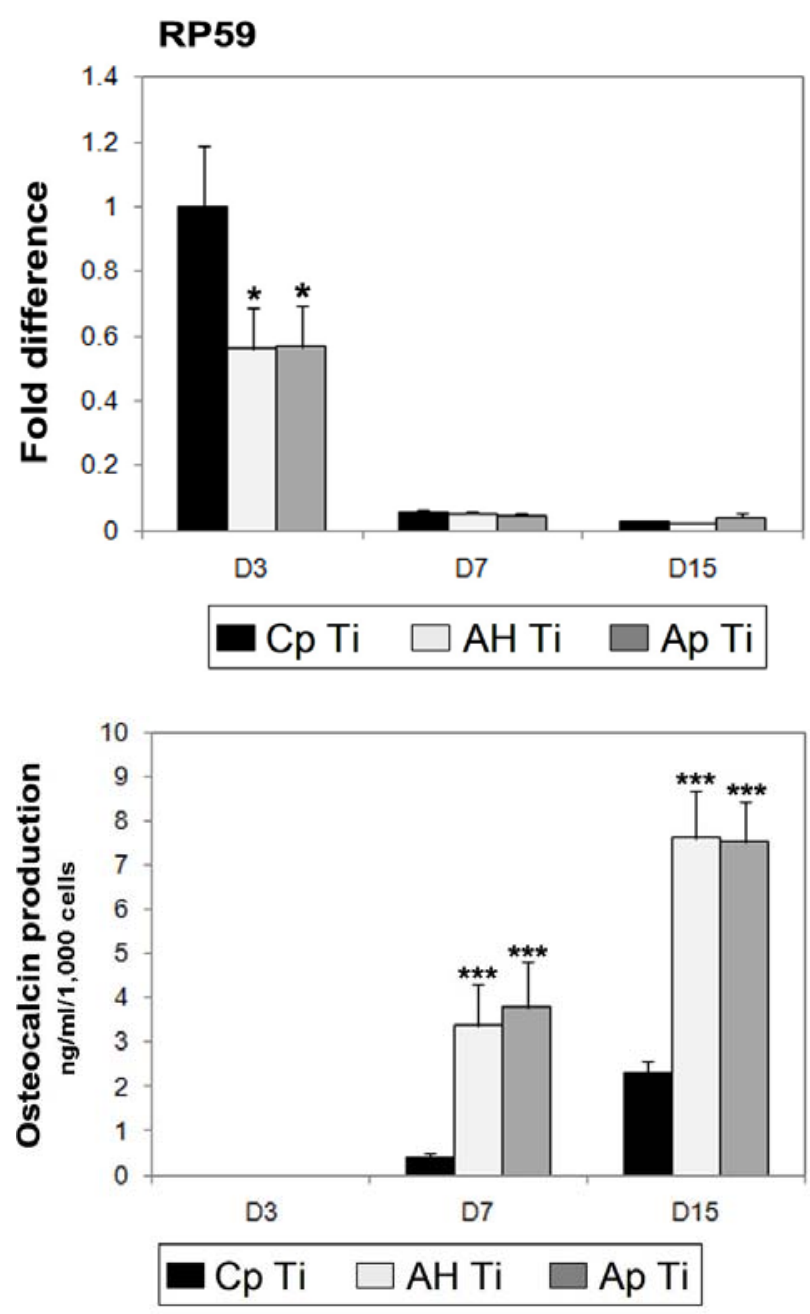

Fig. 7. Real-time PCR analysis of the expression of RP59 on days 3, 7 and 15 in foetal calvarial cells cultured on different substrates: $\mathrm{Cp}$ Ti, AH Ti and Ap Ti. mRNA levels of the genes of interest have been normalised to expression levels of the housekeeping gene GAPDH and are represented as fold difference relative to $\mathrm{Cp}$ Ti on day 3 . At the same time point, ${ }^{*} p<0.05$ and ${ }^{* *} p<0.01$ indicate a significant difference, compared with cells grown on $\mathrm{Cp}$ $\mathrm{Ti}$; and $\# p<0.05$ indicates a significant difference, compared with cells grown on $\mathrm{AH} \mathrm{Ti}$.

Fig. 8. Osteocalcin $(\mathrm{OC})$ protein production by osteoblastic cells grown on $\mathrm{Cp} \mathrm{Ti}, \mathrm{AH}$ Ti and Ap Ti surfaces on days 3,7 and 15. Data are expressed as OC $(\mathrm{ng} / \mathrm{mL})$ secreted during $48 \mathrm{~h}$ in the serum-free medium, and normalised to the total cell count. At the same time point, * $p<0.05, * * p<0.01$ and $* * * p<0.001$ indicate a significant difference, compared with cells grown on $\mathrm{Cp}$ $\mathrm{Ti}$; and $\# p<0.05$ indicates a significant difference, compared with cells grown on AH Ti. substantial increase in expression over the following days of culture $(p<0.01)$ (Fig. 5). However, the magnitude of this observed increase was dependent on the titanium surface being investigated. Thus, on day 15, cells grown on the AH Ti and Ap Ti surfaces showed significantly higher expression levels of these genes than those grown on Cp Ti surfaces; thus, BSP, OC and DMP1 mRNA levels were around three times higher on AH Ti and Ap Ti surfaces than on $\mathrm{Cp} \mathrm{Ti}$.

To further investigate the effects of titanium surfaces on osteoblastic differentiation of calvarial bone cells, we studied the mRNA levels of selected transcription factors. Msx2 mRNA levels were detected throughout the culture period, with a strong and stable expression on days 3 and 7 , followed by a significant decrease in expression levels on day 15 , for all treated surfaces $(p<0.05)$ (Fig. 6). On days 3 and 7, Msx 2 mRNA levels were significantly lower for both $\mathrm{AH}$ Ti and Ap Ti surfaces than for Cp Ti. However, on day 15, we did not find any significant differences between the three different surfaces. Overall, Runx2 (Cbfa1) and Dlx 5 showed similar expression profiles for all tested surfaces, showing a gradual and significant increase up to day $7(p<0.05)$; their expression levels then remained stable up to day 15 (NS) (Fig. 6). Osterix (Osx) mRNA levels increased gradually and significantly throughout the 15 days of culture for all surfaces tested $(p<0.01)$ (Fig. 6). Cells grown on both AH Ti and Ap Ti surfaces showed significantly higher Runx2 and Osx mRNA levels than those grown on Cp Ti surfaces, at all time points. Dlx5 gene expression levels for $\mathrm{AH}$ Ti and Ap Ti surfaces were also higher than $\mathrm{Cp}$ Ti surfaces on day 15 .

We also analysed the transcription profile for the protein RP 59. RP59 mRNA levels decreased considerably over the culture period for all titanium surfaces $(p<0.01)$, with levels 17 times (Cp Ti surfaces), 11 times (AH Ti surfaces) and 12 times (Ap Ti surfaces) lower on day 7 than on day 3 (Fig. 7). On day 3, both AH Ti and Ap Ti surfaces showed lower levels of RP59 gene expression than $\mathrm{Cp}$ Ti surfaces. On days 7 and 15, however, we did not find any significant differences in RP59 gene expression levels between the three titanium surfaces.

Finally, osteocalcin protein production was assayed by EIA. OC protein levels were not detectable on day 3 but significantly increased over the observation period for all titanium surfaces tested $(p<0.05)$ (Fig. 8). Furthermore, whereas no significant differences were observed between AH Ti and Ap Ti surfaces, we found that secreted OC levels were significantly higher for the two treated surfaces than for $\mathrm{Cp}$ Ti on days 7 and 15, with a three-fold difference between the two treated surfaces (AH Ti and Ap Ti) and $\mathrm{Cp}$ Ti surfaces observed on day 15 . 


\section{Discussion}

Over ten years ago, Kim et al. developed a thermochemical treatment resulting in the formation of an alkali titanate layer on titanium surface (Kim et al., 1996). When implanted in bony sites, this modified titanium shows bonebinding ability due to the bone-like apatite layer formed on its surface (Kim et al., 1997). This bioengineered titanium was thus classified as a bioactive metal. It has since been widely characterised and successfully tested in clinical trials for orthopaedic use; however, its mechanism of action on peri-implant bone cells is not yet fully understood.

The aim of this study was to investigate the effects of thermo-chemical treated surfaces on phenotypic changes associated with the process of osteoblast differentiation.

As the use of cell lines often leads to incomplete patterns of osteoblastic differentiation (Cooper et al., 1998) with cells exhibiting various mechanisms of attachment (Kilpadi et al., 2004), in this study we used a primary cell culture model of foetal mouse osteoblasts isolated from calvaria. Indeed, the culture of calvarial bone cells in an osteogenic medium promotes the proliferation and commitment of osteoprogenitor cells to mature osteoblasts (Nefussi et al., 1985; Owen et al., 1990).

Osteoblast differentiation and subsequent bone formation is a gradual, well orchestrated process associated with changes in gene expression over time and characterised in vitro by three developmental stages: proliferation, extracellular matrix production and maturation, and matrix mineralization (Owen et al., 1990). Using this modelling of osteoblast differentiation, we monitored by real-time RT-PCR the bone gene expression patterns of calvarial bone cells cultured on alkali- and heattreated titanium (AH Ti), AH Ti soaked in SBF (Ap Ti) and commercially pure titanium (Cp Ti).

Firstly, we investigated the gene expression of early markers associated with proliferative osteoprogenitors: Msx2 and RP59. Msx2, a member of the Msx (Muscle Segment homeobox) family, is a homeobox-containing transcription factor. Several lines of evidence suggested that Msx2 gene expression could be associated with osteoblast proliferation and act as a repressor of osteoblastic differentiation. Indeed, in vivo, Msx2 is expressed in the proliferating mesenchyme of the cranial suture and then decreased in the cells flanking the osteogenic front (De Coster et al., 2007) and, in osteoblast cell cultures, Msx2 is mostly expressed in proliferating cells, with a gradual decrease in activity observed during osteoblast differentiation (Hassan et al., 2004). Moreover, overexpression of the Msx2-encoding gene promotes the proliferation of osteoprogenitor cells, at the same time preventing osteoblastic differentiation (Dodig et al., 1999; Liu et al., 1999) by repressing the activity of osteoblast markers, such as Runx2 (Shirakabe et al., 2001), ALP (Kim et al., 2004), collagen I (Dodig et al., 1999) and osteocalcin (Hassan et al., 2004). These results are in line with a recent study of Marijanovic et al. where the authors conclude that calvarial osteoblasts derived from Msx2 deficient mice showed a lower rate of proliferation and an increased osteoblastic differentiation when compared to osteoblasts derived from wild type mice (Marijanovic et al., 2009). Taken together, these results suggest that Msx2 could act in vivo to maintain the committed osteoblasts of osteogenic front in undifferentiated stage as well as stimulating their proliferation, then enabling the growth of cranial bones. In our study, Msx2 gene expression levels were significantly lower on day 15 than at the earlier time points for all surfaces tested and were lower for both Ap Ti and AH Ti surfaces than for $\mathrm{Cp}$ Ti on days 3 and 7. Interestingly, RP59 mRNA levels were also significantly lower on day 3 for both Ap Ti and AH Ti surfaces than for $\mathrm{Cp} \mathrm{Ti} \mathrm{and}$ then RP59 mRNA decreased sharply after day 3, for all surfaces tested. The RP59 protein has previously been identified as a marker for progenitor cells with the capacity to differentiate into osteoblasts (Wurtz et al., 2001). Indeed, in vivo, RP59 is present at variable levels in bone marrow cells and newly recruited osteoblasts during bone formation (Wurtz and Berdal, 2003) and fracture healing (Chen et al., 2004), with lower levels found in mature osteoblasts. Overall, the gene expression profiles for both Msx2 and RP59 suggested that the proliferation phase is mainly associated with the first days of culture for all three surfaces. Additionally, because our SEM analysis and MTS assay results did not show any cytotoxic effect of the three tested surfaces on calvarial bone cells, we hypothesized that the reduced Msx2 and RP59 mRNA levels observed on Ap Ti and AH Ti surfaces at earlier times of culture may be due to the fact that bioengineered surfaces drive the commitment of osteoprogenitor cells to the osteoblastic phenotype more quickly than $\mathrm{Cp}$ Ti surfaces, where the cells could be longer maintained in a proliferating stage.

To investigate this further, we studied the changes in the main phenotypic bone markers. We showed that ALP mRNA levels increased significantly over the culture period for all surfaces but were significantly higher for both $\mathrm{AH}$ Ti and Ap Ti than for $\mathrm{Cp}$ Ti on day 15. In line with our findings, Nishio et al. previously showed that ALP enzymatic activity levels in rat bone marrow cells grown on Ap Ti and AH Ti surfaces were higher than in those grown on $\mathrm{Cp}$ Ti surfaces on day 14 (Nishio et al., 2000). To further investigate osteoblast differentiation, we then analysed gene expression levels for three transcription factors with major roles in skeletal formation and bone healing: Runx2, Osterix and Dlx5 (Ferguson et al., 1999; Wohl et al., 2009). Runx2 (cbfa1) and Osterix (Osx) are the major osteoblast transcription factors involved in osteoblast differentiation and bone formation. Thus, Runx2 or Osx gene ablation in mice results in a complete absence of bone skeleton (Komori et al., 1997; Nakashima et al., 2002), while forced expression of these genes stimulate transcription of both early and late bone marker genes (Ducy et al., 1997; Tu et al., 2006). Dlx5, a member of the Dlx (Distal-less homeobox) gene family, is considered to be an important regulator of osteoblast differentiation. D1x 5 acts upstream of Runx2 and Osx (Ryoo et al., 2006) and its expression levels gradually increase during osteoblast differentiation (Hassan et al., 2004). In this study, we found that both Ap Ti and AH Ti surfaces significantly promoted the gene expression of these three specific osteoblast 
transcription factors, with higher expression levels observed on these treated surfaces than on $\mathrm{Cp} \mathrm{Ti}$ after two weeks of culture. These findings strongly suggest that both Ap Ti and AH Ti surfaces stimulate osteogenesis through the modulation of the gene expression of transcription factors essential for progression through the osteoblast lineage to a mature osteoblast.

The hierarchical order of events occurring during osteoblast differentiation and maturation is such that collagen type I biosynthesis and ALP enzymatic activity are followed by the secretion of RGD-containing glycoproteins, such as BSP and OP, and then the synthesis of osteocalcin, which is considered to be the most specific marker of mature osteoblasts (Lian et al., 1989). In this study, OP, BSP and OC showed similar gene expression patterns with a significant increase in expression over the 15 days of culture for all titanium surfaces tested, suggesting that calvarial bone cells entered the extracellular matrix production and mineralization phases for all surfaces tested. Furthermore, on day 15, we found that BSP and OC gene expression levels were considerably higher in cells grown on Ap Ti and AH Ti surfaces than in cells grown on $\mathrm{Cp} \mathrm{Ti}$. To determine whether these changes in OC mRNA were also reflected by changes in protein levels, we assessed OC protein secretion by EIA. Consistent with our RT-PCR findings, levels of secreted OC were significantly higher for AH Ti and Ap Ti surfaces than for $\mathrm{Cp} \mathrm{Ti}$ on days 7 and 15. Our observations concerning OC mRNA levels were in line with previous results obtained by northern blot in rat bone marrow cell culture (Nishio et al., 2000).

Interestingly, in our study, we observed no significant stimulation of OP and Collagen I expression levels for $\mathrm{AH}$ $\mathrm{Ti}$ or Ap Ti surfaces, relative to $\mathrm{Cp}$ Ti surfaces. This is consistent with Nishio et al., who showed no significant differences in OP mRNA levels between $\mathrm{Cp} \mathrm{Ti,} \mathrm{AH} \mathrm{Ti} \mathrm{and}$ Ap Ti surfaces using northern blot analysis (Nishio et al., 2000). Similarly, Hattar et al. reported that sol-gel bioactive glasses up-regulated OC, but not OP, mRNA levels in mouse calvaria osteoblast cultures (Hattar et al., 2006). Taken together, these findings suggest that bioactive surfaces differentially modulate bone marker gene expression

Osteocytes are terminally differentiated cells of the osteoblast lineage that reside in lacunae within the mineralized bone matrix. Recently DMP1, an extracellular matrix protein member of the SIBLING family, has been identified as one of the most informative osteocyte markers in vivo (Feng et al., 2006; Toyosawa et al., 2001). In our study, the expression levels of DMP1 substantially increased by day 15 for all conditions. This observation, in line with previous studies showing the presence of osteocytes inside bone nodules formed in vitro by rat calvaria-released cells using TEM (Nefussi et al., 1991) or SEM (Loty et al., 2000), suggested the presence of osteocytes on all three titanium surfaces at late stages of culture. Interestingly, on day 15, DMP1 mRNA levels were significantly higher in cells grown on Ap Ti and AH Ti surfaces than on $\mathrm{Cp}$ Ti surfaces, possibly demonstrating enhanced osteocyte activity on Ap Ti and AH Ti surfaces.
Our results for bone marker gene expression levels and osteocalcin secretion strongly suggested that osteoblast differentiation of calvarial bone cells cultured on Ap Ti and $\mathrm{AH}$ Ti surfaces was stimulated to a greater extent than the differentiation of cells grown on $\mathrm{Cp} \mathrm{Ti}$.

Our surface characterisations (mainly XPS-based, helped by SEM and EDX, at a $\mu \mathrm{m}$ scale) in line with chemical data obtained by AES, thin-film X-ray diffraction and laser Raman spectroscopy (TF-XRD) (Kim et al., 1999) and surface roughness measurements (Nishio et al., 2000) revealed major differences in chemical composition and topography between $\mathrm{Cp} \mathrm{Ti,} \mathrm{AH} \mathrm{Ti} \mathrm{and} \mathrm{Ap} \mathrm{Ti} \mathrm{surfaces.}$ These surface characteristics may affect biological and chemical events occurring on biomaterial surfaces, such as protein adsorption from blood or serum, or surface chemical modifications. To gain an improved understanding of the differences we observed between the three titanium substrates in the present in vitro study, but also of the in vivo differences previously reported (Yan et al., 1997), we carried out an in vitro study of the physicochemical surface reactivity of $\mathrm{Cp} \mathrm{Ti}, \mathrm{AH}$ Ti and Ap Ti surfaces by XPS and EDX. Our results presented and further discussed in the supplementary data showed that the estimated proportion of the surface covered by adsorbed serum proteins differed between the three substrates and confirmed the bioactivity of $\mathrm{AH} \mathrm{Ti}$, illustrated by surface calcium and phosphate deposition when immersed in biological fluids.

Finally, our results suggested that the stimulating effect of $\mathrm{AH} \mathrm{Ti}$ and $\mathrm{Ap} \mathrm{Ti}$ surfaces on the osteoblast differentiation of calvarial bone cells, relative to $\mathrm{Cp} \mathrm{Ti}$ surface, was essentially due to the bone-like apatite layer formed on AH Ti and Ap Ti surfaces during the cell culture period (for AH Ti) or during the SBF soaking (for Ap Ti). These observations were in line with Hench, who suggested that the formation of a surface apatite layer is a prerequisite for the bioactivity of materials, not only because apatite is a principal component of bone crystal, but also because the apatite layer formed on bioactive materials may provide a favourable template for protein adsorption (Hench, 1991).

\section{Conclusions}

Our findings indicate that alkali-and heat-treated titanium (AH Ti) and AH Ti soaked in SBF (Ap Ti) stimulate the in vitro osteogenic potential of foetal mouse calvarial-derived cells to a greater extent than medical grade commercially pure titanium (Cp Ti). Indeed, AH Ti and Ap Ti surfaces promote cell progression through the osteoblast lineage from osteoprogenitor cells to mature osteocytes, as shown by a significant increase of OC protein production associated with the up-regulation of mRNA levels of Runx2, Osx, Dlx5, ALP, BSP, OC and DMP1 after 15 days of culture on AH Ti and Ap Ti surfaces, with respect to Cp Ti. These stimulatory effects may be due to surface bioactivity and/or protein adsorption.

Finally, our findings suggest that a simple thermochemical treatment of titanium surfaces enhance the biological activity of titanium implants. These 
bioengineered titanium surfaces may have a great potential for future dental applications as a template for enhanced osseointegration.

\section{Acknowledgments}

This work was supported by the Avenir Foundation (Project $n^{\circ}$ ET7-462). The authors thank David Montero and Audrey Asselin for technical assistance. This study represents part of the dissertation of Juliane Isaac's PhD degree at the University Paris Descartes, France.

\section{Supplementary Data}

\section{In vitro chemical evaluation of substrate surface reactivity}

Two approaches were used to study the in vitro chemical reactivity of $\mathrm{Cp} \mathrm{Ti,} \mathrm{AH}$ Ti and $\mathrm{Ap}$ Ti surfaces: we investigated the adsorption of serum proteins on these titanium surfaces by XPS, and the surface chemical modifications in cell-free culture medium by EDX.

The reactivity of the substrates towards the proteins of the FCS was detected by the presence of the $\mathrm{N} 1 \mathrm{~s}$ core level peak signal (XPS survey spectra of Fig. 1a and Fig. 1b). At higher energy resolution, the $\mathrm{N}$ 1s core level presented a symmetrical peak centred at $400.1 \pm 0.1 \mathrm{eV}$, characteristic of nitrogen in amide (mainly) and/or amine groups (Fig.S1a). This signal can be used as a marker of adsorbed proteins. The C 1s XPS core level spectra obtained after serum adsorption (Fig.S1b) showed three contributions (see details in (Ithurbide et al., 2007; Payet et al., 2008)), corresponding to the well defined carbon bonds present in the proteins. These observations were consistent with previous data from Burgos-Asperilla et al. (Burgos-Asperilla et al., 2010). Spectral contributions observed at $286.4 \pm 0.2 \mathrm{eV}$, labelled $\mathrm{C} 2$ and corresponding to $\mathrm{C}-\mathrm{N}$ and $\mathrm{C}-\mathrm{O}$ single bonds, and at $288.3 \pm 0.2 \mathrm{eV}$, labelled $\mathrm{C} 3$ and corresponding to $\mathrm{N}-\mathrm{C}=\mathrm{O}$ bonds, were of particular interest. The N 1s and C 1s core level peaks were better resolved for $\mathrm{Cp}$ Ti samples (smaller full widths at half maximum) than for AH Ti and Ap Ti samples, which are thicker, rougher, and more insulating samples. N/ $\mathrm{C} 2+\mathrm{C} 3$ atomic ratios were systematically calculated for $\mathrm{Cp}$ Ti surfaces. The obtained value of $0.49 \pm 0.08$ corresponded to the theoretical ratio calculated from amino-acid compositions, for example of albumin or fibronectin molecules (Lhoest et al., 2001)). This result thus suggested that the interaction of $\mathrm{Cp}$ Ti surface with serum resulted in the chemical adsorption of the proteins present in the serum (according to the provider, albumin is the major protein in the FCS). Moreover, as regards the Ti $2 p, C a 2 p$ and $P$ 2p core levels, the treatment with the serum did not affect the surface chemical composition of $\mathrm{Cp} \mathrm{Ti}, \mathrm{AH} \mathrm{Ti}, \mathrm{Ap} \mathrm{Ti}$ surfaces, in our conditions. An equivalent thickness of adsorbed protein was then determined, assuming a layer model where all protein (taken as albumin in the calculations) is adsorbed in a continuous homogeneous layer on titanium oxide (taken as $\mathrm{TiO}_{2}$ ) or apatite. By using the attenuation of the XPS signals, i. e. $\frac{I_{N}^{\text {adsorbed } \mathrm{FCS}}}{I_{T i}^{\mathrm{TiO}}}$

for both $\mathrm{Cp} \mathrm{Ti}$ and $\mathrm{AH} \mathrm{Ti}$, and $I_{N}^{\text {adsorbed FCS }}$

or $\frac{I_{N}^{\text {adsorbed FCS }}}{I_{P}^{\text {apatite }}}$

for $\mathrm{Ap} \mathrm{Ti}_{P}$, where $\mathrm{I}_{\mathrm{Ti}}^{\mathrm{TiO}}{ }_{2}$ is the intensity of $\mathrm{Ti}$ in $\mathrm{TiO}_{2}$ from the Ti $2 p_{3 / 2}$ core level peak, $I_{N}^{\text {adsorbed FCS }}$ is the intensity of $\mathrm{N}$ from the $\mathrm{N} 1 \mathrm{~s}$ core level peak, $I_{\mathrm{Ca}}^{\text {apatie }}$ is the intensity of $\mathrm{Ca}$ from the Ca $2 \mathrm{p}$ core level peak, and $I_{P}^{\text {apatite }}$ is the intensity of $\mathrm{P}$ from the $\mathrm{P} 2 \mathrm{p}$ core level peak, the adsorbed protein equivalent layer was estimated at $4.2 \pm 0.2 \mathrm{~nm}$ for both $\mathrm{Cp}$ Ti and AH Ti surfaces, and $3.3 \pm 0.3 \mathrm{~nm}$ for Ap Ti surfaces (average value from the calculations with $\mathrm{Ca} 2 \mathrm{p}$ and $\mathrm{P} 2 \mathrm{p}$ core levels). Protein adsorption was also quantitatively evaluated using a model of islands of adsorbed proteins on the surface for XPS calculations (Payet et al., 2010). In this model, the height of the islands was considered as "infinite" (>10 nm, as defined by the XPS probed depth)

Table S1. EDX microanalysis on Ti samples soaked in cell-free culture medium.

\begin{tabular}{|c|c|c|c|c|c|c|c|c|c|c|}
\hline $\begin{array}{c}\text { Atomic } \\
\text { \% }\end{array}$ & $\mathbf{D a y}$ & $\mathbf{P}$ & $\mathbf{C a}$ & $\mathbf{N a}$ & $\mathbf{M g}$ & $\mathbf{C l}$ & $\mathbf{O}$ & $\mathbf{C}$ & $\mathbf{T i}$ & $\mathbf{C a} / \mathbf{P}$ \\
\hline $\mathbf{C p ~ T i}$ & $\mathrm{D} 3$ & 0.18 & 0.08 & 3.22 & 0.09 & 1.16 & 8.66 & 29.27 & 57.35 & 0.44 \\
\hline $\mathbf{C p ~ T i}$ & $\mathrm{D} 15$ & 0.18 & 0.09 & 2.11 & 0.16 & 0.78 & 9.39 & 32.89 & 54.40 & 0.50 \\
\hline $\mathbf{A H} \mathbf{~ T i}$ & $\mathrm{D} 3$ & 0.37 & 0.41 & 2.69 & 0.16 & 0.53 & 41.13 & 28.44 & 26.27 & 1.11 \\
\hline $\mathbf{A H}$ Ti & $\mathrm{D} 7$ & 0.65 & 0.84 & 2.90 & 0.19 & 0.63 & 43.69 & 24.97 & 26.13 & 1.29 \\
\hline $\mathbf{A H} \mathbf{~ T i}$ & $\mathrm{D} 15$ & 1.18 & 1.51 & 2.23 & - & 0.32 & 40.37 & 32.34 & 22.06 & 1.28 \\
\hline $\mathbf{A p ~ T i}$ & $\mathrm{D} 3$ & 8.85 & 13.34 & 1.17 & 0.75 & 0.59 & 42.82 & 31.64 & 0.83 & 1.50 \\
\hline
\end{tabular}

Semi-quantitative chemical analysis assessed by energy dispersive X-ray (EDX) microanalysis on titanium samples soaked in cell-free culture medium for different durations (3, 7, 15 days). Atomic percentages of phosphorus, calcium, sodium, magnesium, chlorine, oxygen, carbon and titanium and the atomic calcium/phosphorus ratio are reported. 

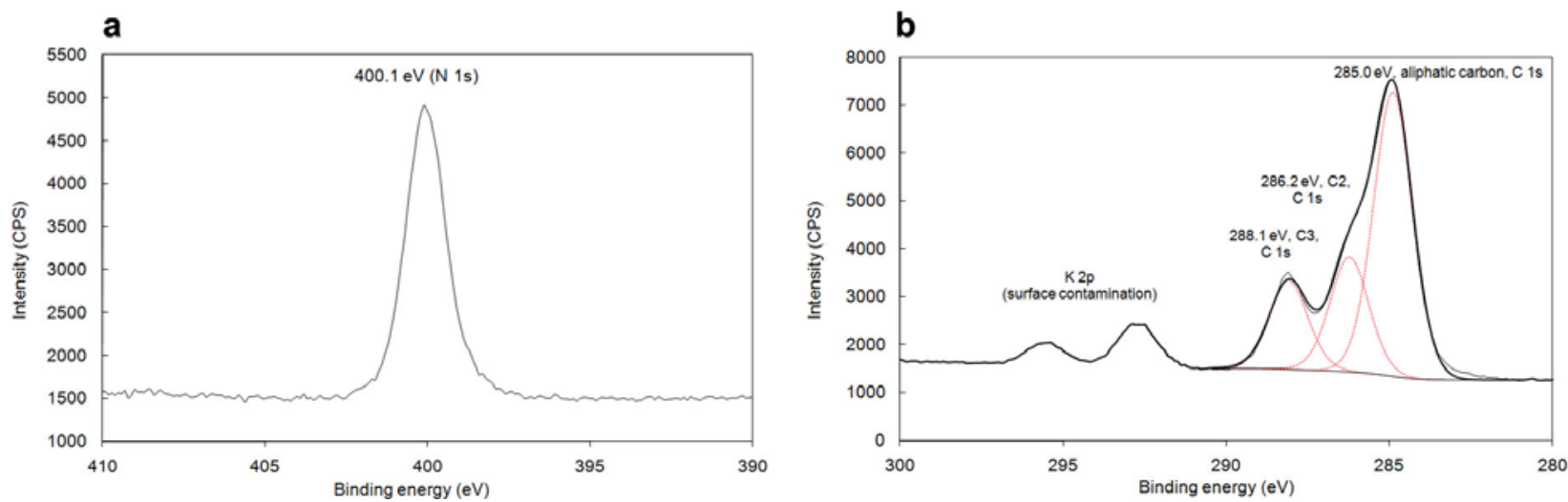

Fig. S1. XPS N 1s (a) and C 1s (b) core level spectra for Cp Ti after treatment with $\mathrm{FCS}$, at $37^{\circ} \mathrm{C}$, pH 7.4, for 1 hour. The C 1s core level spectrum is decomposed into three components (see text for details).
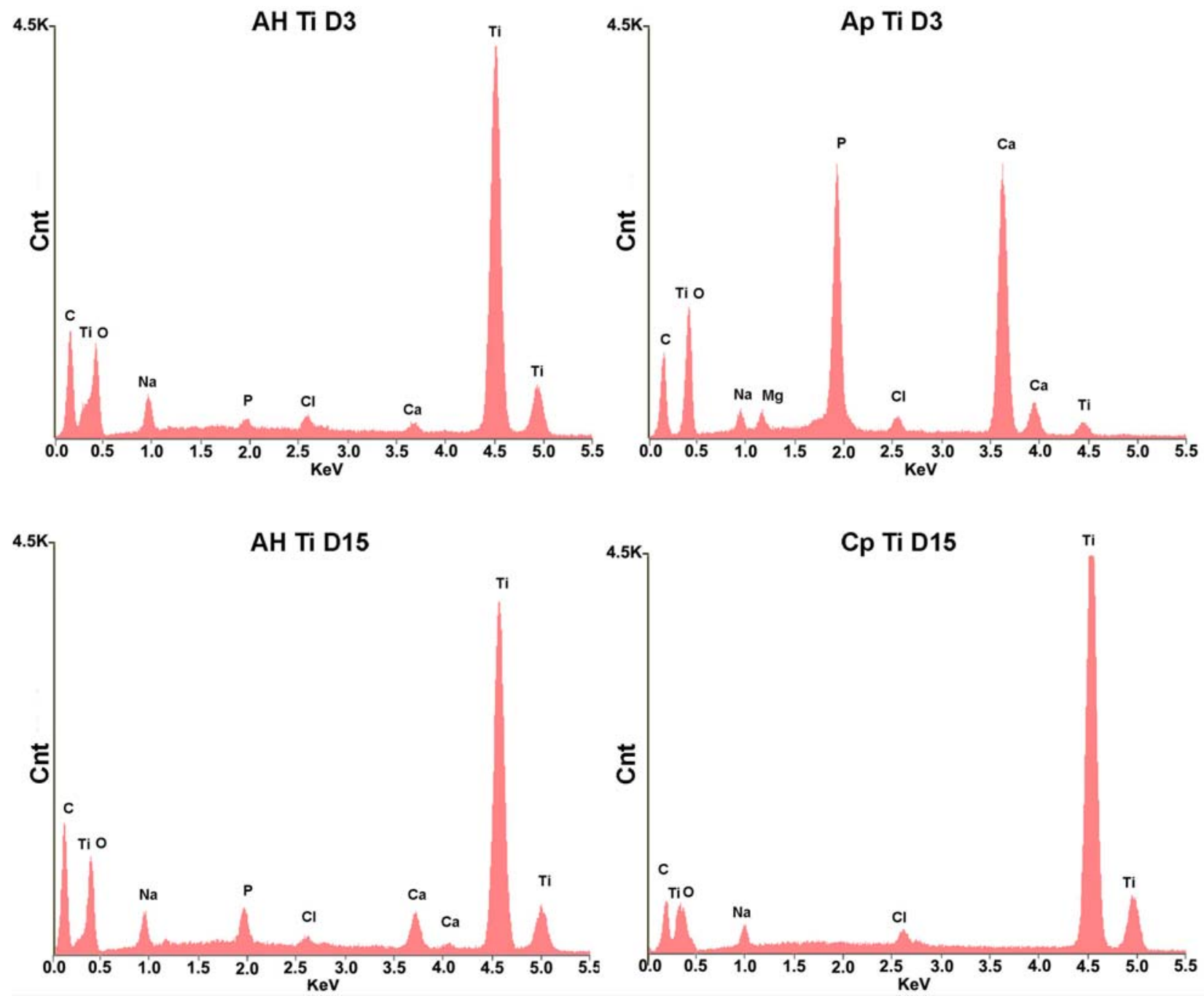

Fig. S2. Spectral analysis of chemical composition, assessed by energy dispersive X-ray microanalysis (EDX) on titanium samples soaked in cell-free culture medium for 3, 7 and 15 days). Detected atoms were phosphorus (P), calcium $(\mathrm{Ca})$, sodium $(\mathrm{Na})$, magnesium $(\mathrm{Mg})$, chlorine $(\mathrm{Cl})$, oxygen $(\mathrm{O})$, carbon $(\mathrm{C})$ and titanium $(\mathrm{Ti})$.

and the ratio of the intensity signals from the substrate before ( $\mathrm{I}_{\mathrm{Ti},[\mathrm{PBS}]}^{\mathrm{TiO}_{2}}$ or $\left.\mathrm{I}_{\mathrm{Ca},[\mathrm{PBS}]}^{\text {apatite }}\right)$ and after $\left(\mathrm{I}_{\mathrm{Ti},[\mathrm{FCS}]}^{\mathrm{TiO}_{2}}\right.$ or $\left.\mathrm{I}_{\mathrm{Ca},[\mathrm{FCS}]}^{\text {apatte }}\right)$

treatment with the serum solution provides an estimation of the surface coverage by adsorbed proteins (Aeimbhu et al., 2005). The $\frac{\mathrm{I}_{\mathrm{Ti},[\text { [FS }}^{\mathrm{Ti} \mathrm{O}_{2}}}{\mathrm{I}_{\mathrm{Ti},[\mathrm{PBS}]}^{\mathrm{Ti}}}$

intensity ratio tended to 0.4 , corresponding to a fraction of 0.6 of the surface covered by the adsorbed protein on $\mathrm{Cp}$ Ti and AH Ti samples. The $\frac{\mathrm{I}_{\mathrm{Ca} a \mathrm{FCS}]}^{\text {apatite }}}{\mathrm{I}_{\mathrm{Ca}[\mathrm{PBS}]}^{\mathrm{apatite}}}$

intensity ratio tended to 0.7 , corresponding to a fraction 
of 0.3 of the surface covered by the adsorbed protein on Ap Ti samples. Thus, our XPS results showed that the equivalent thickness of a continuous (and homogeneous) adsorbed protein layer remained quite similar between the three tested surfaces, with an adsorbed protein layer thickness of nearly $4 \mathrm{~nm}$. However, using the model of islands that we considered as more realistic in the case of protein adsorption, the estimated percentage of the surface covered by proteins from the serum significantly differed between the surfaces. Indeed, with a much lower surface coverage (30\%), Ap Ti presented a different behaviour than $\mathrm{Cp}$ Ti and AH Ti (surface coverage of $60 \%$ ).

At a larger time scale, the Ti-based substrates were immersed in cell-free culture medium up to 15 days and surface topography and chemical modifications were analysed by SEM observations and EDX microanalysis. No differences in surface topography were observed for Ti-based samples soaked in cell-free culture medium for 3, 7 and 15 days, using SEM (data not shown). EDX microanalysis showed that the initial chemical composition of $\mathrm{Cp}$ Ti and Ap Ti samples remained unchanged during the investigation period (Fig. S2 and Table S1). Thus, Cp Ti samples were mostly composed of titanium, whereas Ap Ti first $\mu \mathrm{m}$ were mainly composed of $\mathrm{Ca}$ and $\mathrm{P}$. However, EDX revealed changes in the chemical composition of AH Ti over time (Fig.S2 and Table S1). Indeed, EDX spectra obtained for AH Ti showed that both $\mathrm{Ca}$ and $\mathrm{P}$ were present and that the atomic percentages of these elements increased with soaking time from day 3 to day 15. This mineral layer was richer in calcium than in phosphorus with a $\mathrm{Ca} / \mathrm{P}$ atomic ratio of $1.30 \pm 0.30$ after 7 days of incubation (Table S1). Taken into account the EDX experimental uncertainty, this atomic ratio is in reasonable agreement with the theoretical value of 1.67 expected for stoichiometric apatite. Note that all tested surfaces were associated with small amounts of sodium, magnesium and chlorine that were most probably contaminants from the culture medium and PBS (and SBF for Ap Ti samples), except for AH Ti surface where the Na signal should correspond both to the sodium titanate layer and contamination from PBS and culture medium. These findings illustrated the reactivity of AH Ti surface. Indeed, our EDX analyses showed that, from the first three days of immersion in cell-free culture medium, calcium and phosphorus deposition occurred on AH Ti surfaces (Table $\mathrm{S} 1)$. These observations were consistent with previous in vivo and in vitro studies (Kokubo et al., 2004), reporting that, after alkali- and heat-treatments, titanium implants can initiate apatite nucleation on its surface through ions exchange with biological fluids. We also showed that the atomic percentages of $\mathrm{Ca}$ and $\mathrm{P}$ elements gradually increased from day 3 to day 15 , suggesting that the Ca-P layer on the AH Ti surface grew with soaking time in the cell-free culture medium.

Finally, our observations may explain why the $\mathrm{AH} \mathrm{Ti}$ and Ap Ti surfaces exhibited similar in vitro osteostimulator potential at later times of culture. Indeed, taking into account the quite similar chemical composition of AH Ti and $\mathrm{Cp} \mathrm{Ti} \mathrm{(even} \mathrm{if} \mathrm{the} \mathrm{structural} \mathrm{bulk} \mathrm{composition} \mathrm{differs),}$ protein adsorption from serum on substrate surfaces may be directly correlated to the surface chemical composition. Thus, given that the surface of AH Ti rapidly changed in the chemical composition to form an apatite-like surface over time immersed in a biological fluid, we hypothesized that AH Ti surface should display a similar protein adsorption profile to the Ap Ti surface at later times of culture and implantation - in terms of distribution of surface coverage by the adsorbed protein.

\section{References}

Adell R, Lekholm U, Rockler B, Brånemark PI (1981) A 15-year study of osseointegrated implants in the treatment of the edentulous jaw. Int J Oral Surg 10: 387 416.

Aeimbhu A, Castle JE, Singjai P (2005) Accounting for the size of molecules in determination of adsorption isotherms by XPS; exemplified by adsorption of chicken egg albumin on titanium. Surface Interface Anal 37: 11271136.

Albrektsson T (1998) Hydroxyapatite-coated implants: a case against their use. J Oral Maxillofac Surg, 56: 13121326.

Burgos-Asperilla L, Garcia-Alonso MC, Escudero ML, Alonso C (2010) Study of the interaction of inorganic and organic compounds of cell culture medium with a Ti surface. Acta Biomater 6: 652-661.

Buser D, Mericske-Stern R, Bernard JP, Behneke A, Behneke N, Hirt HP, Belser UC, Lang NP (1997) Longterm evaluation of non-submerged ITI implants. Part 1: 8year life table analysis of a prospective multi-center study with 2359 implants. Clin Oral Impl Res 8: 161-172.

Chen YJ, Wurtz T, Wang CJ, Kuo YR, Yang KD, Huang HC, Wang FS (2004) Recruitment of mesenchymal stem cells and expression of TGF-beta 1 and VEGF in the early stage of shock wave-promoted bone regeneration of segmental defect in rats. J Orthop Res 22: 526-534.

Chu CL, Chung CY, Zhou J, Pu YP, Lin PH (2005) Fabrication and characteristics of bioactive sodium titanate/ titania graded film on NiTi shape memory alloy. J Biomed Mater Res 75: 595-602.

Cooper LF, Masuda T, Yliheikkila PK, Felton DA (1998) Generalizations regarding the process and phenomenon of osseointegration. Part II. In vitro studies. IntJ Oral Maxillofac Impl 13: 163-174.

Davies JE (1996) In vitro modeling of the bone/implant interface. Anat Rec 245: 426-445.

De Coster PJ, Mortier G, Marks LA, Martens LC (2007) Cranial suture biology and dental development: genetic and clinical perspectives. J Oral Pathol Med 36:447-455.

Dodig M, Tadic T, Kronenberg MS, Dacic S, Liu YH, Maxson R, Rowe DW, Lichtler AC (1999) Ectopic Msx2 overexpression inhibits and Msx2 antisense stimulates calvarial osteoblast differentiation. Dev Biol 209: 298-307.

Ducy P, Zhang R, Geoffroy V, Ridall AL, Karsenty G (1997) Osf2/Cbfa1: a transcriptional activator of osteoblast differentiation. Cell 89: 747-754.

Feng JQ, Ward LM, Liu S, Lu Y, Xie Y, Yuan B, Yu X, Rauch F, Davis SI, Zhang S, Rios H, Drezner MK, Quarles 
LD, Bonewald LF, White KE (2006) Loss of DMP1 causes rickets and osteomalacia and identifies a role for osteocytes in mineral metabolism. Nat Genet 38: 1310-1315.

Ferguson C, Alpern E, Miclau T, Helms JA (1999) Does adult fracture repair recapitulate embryonic skeletal formation? Mech Dev 87: 57-66.

Ferraz MP, Monteiro FJ, Santos JD (1999) CaO-P2O5 glass hydroxyapatite double-layer plasma-sprayed coating: in vitro bioactivity evaluation. J Biomed Mater Res 45: 376-383.

Hassan MQ, Javed A, Morasso MI, Karlin J, Montecino M, van Wijnen AJ, Stein GS, Stein JL, Lian JB (2004) Dlx3 transcriptional regulation of osteoblast differentiation: temporal recruitment of Msx2, Dlx3, and Dlx 5 homeodomain proteins to chromatin of the osteocalcin gene. Mol Cell Biol 24: 9248-9261.

Hattar S, Loty S, Gaisser D, Berdal A, Sautier JM (2006) Effects of 58S sol-gel glasses on the temporal expression of bone markers during mouse osteoblastic differentiation. J Biomed Mater Res 76: 811-819.

Hayes JS, Vos DI, Hahn J, Pearce SG, Richards RG (2009) An in vivo evaluation of surface polishing of TAN intermedullary nails for ease of removal. Eur Cell Mater 18: $15-26$.

Hench LL (1991) Surface reaction kinetics and adsorption of biological moieties : a mechanistic approach to tissue attachment. In: The Bone-Biomaterials Interface (Davies JE, ed), University of Toronto, pp 33-48.

Isaac J, Loty S, Hamdan A, Kokubo T, Kim HM, Berdal A, Sautier JM (2009) Bone-like tissue formation on a biomimetic titanium surface in an explant model of osteoconduction. J Biomed Mater Res A 89: 585-593.

Ithurbide A, Frateur I, Galtayries A, Marcus P (2007) XPS and flow-cell EQCM study of albumin adsorption on passivated chromium surfaces: Influence of potential and pH Electrochim Acta 53: 1336-1345.

Kilpadi KL, Sawyer AA, Prince CW, Chang PL, Bellis SL (2004) Primary human marrow stromal cells and Saos2 osteosarcoma cells use different mechanisms to adhere to hydroxylapatite. J Biomed Mater Res 68: 273-285.

Kim HM, Miyaji F, Kokubo T, Nakamura T (1996) Preparation of bioactive Ti and its alloys via simple chemical surface treatment. J Biomed Mater Res 32: 409417.

Kim HM, Miyaji F, Kokubo T, Nakamura T (1997) Bonding strength of bonelike apatite layer to Ti metal substrate. J Biomed Mater Res 38: 121-127.

Kim HM, Miyaji F, Kokubo T, Nishiguchi S, Nakamura $\mathrm{T}$ (1999) Graded surface structure of bioactive titanium prepared by chemical treatment. J Biomed Mater Res 45: 100-107.

Kim YJ, Lee MH, Wozney JM, Cho JY, Ryoo HM (2004) Bone morphogenetic protein-2-induced alkaline phosphatase expression is stimulated by Dlx 5 and repressed by Msx2. J Biol Chem 279: 50773-50780.

Kokubo T, Kim HM, Kawashita M, Nakamura T (2004) Bioactive metals: preparation and properties. J Mater Sci Mater Med 15: 99-107.

Kokubo T, Takadama H (2006) How useful is SBF in predicting in vivo bone bioactivity? Biomaterials 27: 2907 2915.
Komori T, Yagi H, Nomura S, Yamaguchi A, Sasaki K, Deguchi K, Shimizu Y, Bronson RT, Gao YH, Inada M, Sato M, Okamoto R, Kitamura Y, Yoshiki S, Kishimoto $\mathrm{T}$ (1997) Targeted disruption of Cbfa1 results in a complete lack of bone formation owing to maturational arrest of osteoblasts. Cell 89: 755-764.

Lakstein D, Kopelovitch W, Barkay Z, Bahaa M, Hendel D, Eliaz N (2009) Enhanced osseointegration of grit-blasted, $\mathrm{NaOH}$-treated and electrochemically hydroxyapatite-coated Ti-6Al-4V implants in rabbits. Acta Biomater 5: 2258-2269.

Lhoest JB, Wagner MS, Tidwell CD, Castner DG (2001) Characterization of adsorbed protein films by time of flight secondary ion mass spectrometry. J Biomed Mater Res 57: 432-440.

Lian JB, Stein GS, Stewart C, Puchacz E, Mackowiak S, Aronow M, Von Deck M, Shalhoub V (1989) Osteocalcin: characterization and regulated expression of the rat gene. Connect Tissue Res 21: 61-68.

Liu YH, Tang Z, Kundu RK, Wu L, Luo W, Zhu D, Sangiorgi F, Snead ML, Maxson RE (1999) Msx2 gene dosage influences the number of proliferative osteogenic cells in growth centers of the developing murine skull: a possible mechanism for MSX2-mediated craniosynostosis in humans. Dev Biol 205: 260-274.

Loty C, Sautier JM, Boulekbache H, Kokubo T, Kim HM, Forest N (2000) In vitro bone formation on a bonelike apatite layer prepared by a biomimetic process on a bioactive glass-ceramic. J Biomed Mater Res 49: 423-434.

Lu HB, Campbell CT, Graham DJ, Ratner BD (2000) Surface characterization of hydroxyapatite and related calcium phosphates by XPS and TOF-SIMS. Anal Chem 72: 2886-2894.

Marijanovic I, Kronenberg MS, Erceg Ivkosic I, Lichtler AC (2009) Comparison of proliferation and differentiation of calvarial osteoblast cultures derived from Msx2 deficient and wild type mice. Coll Antropol 33: 919924.

Martini D, Fini M, Franchi M, Pasquale VD, Bacchelli B, Gamberini M, Tinti A, Taddei P, Giavaresi G, Ottani V, Raspanti M, Guizzardi S, Ruggeri A (2003) Detachment of titanium and fluorohydroxyapatite particles in unloaded endosseous implants. Biomaterials 24: 1309-1316.

Munting E (1996) The contributions and limitations of hydroxyapatite coatings to implant fixation: A histomorphometric study of load bearing implants in dogs. Int Orthop 20: 1-6.

Nakashima K, Zhou X, Kunkel G, Zhang Z, Deng JM, Behringer RR, de Crombrugghe B (2002) The novel zinc finger-containing transcription factor osterix is required for osteoblast differentiation and bone formation. Cell 108: $17-29$

Nefussi JR, Boy-Lefevre ML, Boulekbache H, Forest N (1985) Mineralization in vitro of matrix formed by osteoblasts isolated by collagenase digestion. Differentiation 29: 160-168.

Nefussi JR, Sautier JM, Nicolas V, Forest N (1991) How osteoblasts become osteocytes: a decreasing matrix forming process. J Biol Buccale 19: 75-82.

Nishio K, Neo M, Akiyama H, Nishiguchi S, Kim HM, Kokubo T, Nakamura T (2000) The effect of alkali- and 
heat-treated titanium and apatite-formed titanium on osteoblastic differentiation of bone marrow cells. . J Biomed Mater Res 52: 652-661.

Owen TA, Aronow M, Shalhoub V, Shalhoub V, Barone LM, Wilming L, Tassinari MS, Kennedy MB, Pockwinse S, Lian JB, Stein GS (1990) Progressive development of the rat osteoblast phenotype in vitro: reciprocal relationships in expression of genes associated with osteoblast proliferation and differentiation during formation of the bone extracellular matrix. J Cell Physiol 143: 420-430.

Payet V, Brunner S, Galtayries A, Frateur I, Marcus P (2008) Cleaning of albumin-contaminated $\mathrm{Ti}$ and $\mathrm{Cr}$ surfaces : an XPS and QCM study. Surf Interface Anal 40: 215-219.

Payet V, Dini T, Brunner S, Galtayries A, Frateur I, Marcus P (2010) Pre-treatment of titanium surfaces by fibronectin: in situ adsorption and effect of concentration: an XPS and QCM study. Surf Interface Anal DOI: 10.1002/sia.3298.

Pearce AI, Pearce SG, Schwieger K, Milz S, Schneider E, Archer CW, Richards RG (2008) Effect of surface topography on removal of cortical bone screws in a novel sheep model. J Orthop Res 26: 1377-1383.

Pohler OE (2000) Unalloyed titanium for implants in bone surgery. Injury 31 Suppl 4: 7-13.

Ryoo HM, Lee MH, Kim YJ (2006) Critical molecular switches involved in BMP-2-induced osteogenic differentiation of mesenchymal cells. Gene 366: 51-57.

Shirakabe K, Terasawa K, Miyama K, Shibuya H, Nishida E (2001) Regulation of the activity of the transcription factor Runx 2 by two homeobox proteins, Msx2 and Dlx5. Genes Cells 6: 851-856.

Sun L, Berndt CC, Gross KA, Kucuk A (2001) Material fundamentals and clinical performance of plasma-sprayed hydroxyapatite coatings: a review. . J Biomed Mater Res 58: $570-592$.

Toyosawa S, Shintani S, Fujiwara T, Ooshima T, Sato A, Ijuhin N, Komori T (2001) Dentin matrix protein 1 is predominantly expressed in chicken and rat osteocytes but not in osteoblasts. J Bone Miner Res 16: 2017-2026.

Tu Q, Valverde P, Chen J (2006) Osterix enhances proliferation and osteogenic potential of bone marrow stromal cells. Biochem Biophys Res Commun 341: 1257 1265.

Wang BC, Chang E, Lee TM, Yang CY (1995) Changes in phases and crystallinity of plasma-sprayed hydroxyapatite coatings under heat treatment: a quantitative study. J Biomed Mater Res 29: 1483-1492.

Wohl GR, Towler DA, Silva MJ (2009) Stress fracture healing: fatigue loading of the rat ulna induces upregulation in expression of osteogenic and angiogenic genes that mimic the intramembranous portion of fracture repair. Bone 44: 320-330.

Wurtz T, Berdal A (2003) Osteoblast precursors at different anatomic sites. Crit Rev Eukar Gene Expr 13: 147-161.

Wurtz T, Kruger A, Christersson C, Lundmark C (2001) A new protein expressed in bone marrow cells and osteoblasts with implication in osteoblast recruitment. Exp Cell Res 263: 236-242.
Yan WQ, Nakamura T, Kobayashi M, Kim HM, Miyaji F, Kokubo T (1997) Bonding of chemically treated titanium implants to bone. J Biomed Mater Res 37: 267-275.

\section{Discussion with Reviewer}

Reviewer I: The peak increase in OC and DMP1 expression appears around D15 for the treated samples. Did the authors culture for longer time periods to see if this peak occurred also for $\mathrm{Cp} \mathrm{Ti}$ at later stages or was the expression observed at D15 representative of peak expression for $\mathrm{Cp}$ Ti also?

Authors: The expression of Osteocalcin and DMP1 in cells cultured on Cp Ti samples significantly increased over the 15 days of culture. Indeed, OC and DMP1 gene expressions were 61 times and 12 times higher at D15 as compared to D3, respectively. To check that the peak expression of late osteoblast markers (BSP, OC, DMP1 and D1x5) observed at D15 was representative for the investigated surfaces, calvarial cells were cultured on the three titanium samples during 21 days and gene expression pattern of the 11 osteoblast markers investigated in our study were monitored by real-time RT-PCR at D17 and D21.

Our results show that mRNA levels of the early and late osteoblast markers decreased or remained stable after D15, independently of the investigated surface and gene (data not shown). Moreover, SEM microscopic observations performed after D15 showed an important cell death associated with a degradation of the extracellular matrix on the three titanium surfaces, as well as on the Thermanox plastic coverslips. These results suggest that, in our conditions of culture (i.e. osteogenic medium, cell density), primary calvarial cells begin to die by necrosis and/or apoptosis after 2 weeks of culture, making the RT$\mathrm{PCR}$ results inconsistent. These observations were in line with previous studies showing that the process of in vitro osteoblast differentiation is followed by a phase of apoptosis, characterized by the overexpression of apoptosis markers, such as Bcl2, p53 and c-fox (Stein et al., 2004). Thus, our many years of practice with primary calvarial cell cultures led us to focus our gene expression analysis on three time points that reflect the three key stages of osteoblastic differentiation on plastic dishes. These time points (D3, D7 and D15) respectively correspond to 1) the decrease of the proliferating phase and the onset of differentiation, 2) the matrix secretion and maturation, and 3 ) the extracellular matrix mineralization with the peak expression of the specific markers of mature osteoblasts and osteocytes, such as Osteocalcin and DMP1.

Reviewer I: Can the authors comment on the early peak of both OC and DMP-1 after just 15 days culturing? How did this compare to cells cultured on plastic?

Authors: Before we started experiments with titanium samples, we first genetically characterized the primary calvarial cell culture model. For this purpose, calvarial cells were cultured on Thermanox plastic coverslips with a similar cell density and the same osteogenic medium that we used for titanium experimentations. Real-time RT-PCR results on cells cultured on Thermanox plastic coverslips 
showed that OC and DMP1 exhibit a similar expression pattern as compared to cells cultured on $\mathrm{Cp} \mathrm{Ti,} \mathrm{AH} \mathrm{Ti} \mathrm{and}$ Ap Ti surfaces, with a low gene expression at D3 and D7, followed by a substantial increase in expression at D15 (data not shown). However, since the aim of our study was to determine the effects of different titanium surfaces on osteoblast differentiation, we decided to leave out the gene expression profile of the cells grown on Thermanox plastic coverslips (that are specifically treated for cellular adherence) in order to make the manuscript clearer.

Reviewer I: ALP and BSP normally indicate initiation of mineralization and decrease prior to terminal differentiation. However the peak for both these markers are at day 15 , which happens to be the time when OC is also peaked - can the authors consolidate this observation? Authors: The specific function of the alkaline phosphatase enzyme is not yet fully understood. However, as underlined by the reviewer, the ALP enzyme is assumed to play a role in the process of matrix mineralization and more specifically in its initiation (Bellows et al., 1991; Kay and Robison, 1924). In line with this hypothesis, a human mutation of the ALP gene is associated with hypophosphatasia (OMIM 241500) (for review (Mornet, 2007)), and deletion of ALP in mice induces mineralization disorders (Wennberg et al., 2000).

In vitro, ALP is widely used as an early marker of osteoblast differentiation, with peak level occurring in postproliferative cells during osteoblast maturation (Garcia et al., 2002; Lian and Stein, 1992).

Surprisingly, in our study, RT-PCR results showed a significant increase of ALP mRNA levels over the 15 days of culture for all the investigated surfaces (including Thermanox plastic coverslips (data not shown)). Unfortunately, the ALP enzymatic activity was not monitored because of the size of the titanium samples $\left(1 \mathrm{~cm}^{2}\right)$ that did not allow us to obtain sufficient organic material (even by pooling triplicate samples). However, ALP gene expression was monitored by real-time RT-PCR on three independent experiments and all data showed a similar expression pattern. Although this profile could appear in contradiction with the expected in vitro expression of ALP, previous studies using primary bone cells cultured in osteogenic media on various surfaces also reported an increasing or a stable expression of the ALP mRNA level and/or enzymatic activity after 2 or 3 weeks of cultures (Hattar et al., 2006; Isaac et al., 2008; Nishio et al., 2000). Thus, these in vitro observations showed that sustained gene expression of ALP does not prevent the peak expression of mature osteoblast markers such as OC, BSP and DMP1. This suggests that ALP expression does not inhibit extracellular matrix production and mineralization in vitro. However, further studies are needed to conclude on the specific role of ALP during osteoblast terminal differentiation.

Reviewer I: Both Runx2 and Osx are known to be involved with osteoblast determination and early differentiation. Their expression peaks during early differentiation and then returns to basal levels. Furthermore, prolonged Runx 2 has been observed to have a negative impact on osteoblast terminal differentiation. Can the authors therefore comment on the fact that both these markers have maintained increases in expression over time while still observing peak expression of OC, BSP, and ALP at D15?

Authors: Runx2 is an essential transcription factor for the commitment of pluripotent mesenchymal stem cells toward the osteoblast lineage (for review (Stein et al., 2004)). However, the role of Runx2 in post-natal bone development and maintenance remains to be clarified. In vivo Runx 2 is strongly expressed in preosteoblasts and is weakly detected in many osteocalcin-positive mature osteoblasts and its expression decreases during mouse aging (Maruyama et al., 2007). As underlined by the reviewer, previous studies also suggest a negative impact of Runx 2 on osteoblast terminal differentiation. Indeed, in vivo overexpression of Runx2 in mature osteoblasts increases bone resorption and blocks terminal osteoblast differentiation (Geoffroy et al., 2002; Liu et al., 2001).

In our study, real-time RT-PCR analyses showed that both Runx2 and Osterix mRNA levels increase and remain to a high level up to D15 for each surface tested. These profiles are in line with many in vitro studies using primary bone cells in the field of biomaterials (see for examples (Hattar et al., 2006; Tsigkou et al., 2009)).

These observations led us to hypothesize that mRNA level of these two transcription factors was maintained and/ or increased over the culture period because of the heterogeneity of our primary cell culture model. Indeed, previous works studying the sequential expression of bone matrix proteins during osteoblast differentiation of rat calvarial cells have highlighted the simultaneous presence of bone cells at various differentiation stages (e.g. osteoprogenitors, preosteoblasts and mature osteoblasts) (Nefussi et al., 1997).

Further analyses using flow cytometry could be performed to obtain a homogeneous cell population. However, as the peri-implant bone-healing environment is composed of a heterogeneous cell population in vivo, we believe that the calvarial bone cell model is relevant to investigate the in vitro effects of biomaterials on osteoblast differentiation.

\section{Additional References}

Bellows CG, Aubin JE, Heersche JN (1991) Initiation and progression of mineralization of bone nodules formed in vitro: the role of alkaline phosphatase and organic phosphate. Bone Miner 14: 27-40.

Garcia T, Roman-Roman S, Jackson A, Theilhaber J, Connolly T, Spinella-Jaegle S, Kawai S, Courtois B, Bushnell S, Auberval M, Call K, Baron R (2002) Behavior of osteoblast, adipocyte, and myoblast markers in genomewide expression analysis of mouse calvaria primary osteoblasts in vitro. Bone 31: 205-211.

Geoffroy V, Kneissel M, Fournier B, Boyde A, Matthias P (2002) High bone resorption in adult aging transgenic mice overexpressing cbfa1/runx 2 in cells of the osteoblastic lineage. Mol Cell Biol 22: 6222-6233. 
Isaac J, Hornez JC, Jian D, Descamps M, Hardouin P, Magne D (2008) beta-TCP microporosity decreases the viability and osteoblast differentiation of human bone marrow stromal cells. J Biomed Mater Res 86: 386-393.

Kay HD, Robison R (1924) The Possible Significance of Hexosephosphoric Esters in Ossification. . Biochem J 18: $740-769$.

Lian JB, Stein GS (1992) Concepts of osteoblast growth and differentiation: basis for modulation of bone cell development and tissue formation. Crit Rev Oral Biol Med 3: 269-305.

Liu W, Toyosawa S, Furuichi T, Kanatani N, Yoshida C, Liu Y, Himeno M, Narai S, Yamaguchi A, Komori T (2001) Overexpression of Cbfa1 in osteoblasts inhibits osteoblast maturation and causes osteopenia with multiple fractures. J Cell Biol 155: 157-166.

Maruyama Z, Yoshida CA, Furuichi T, Amizuka N, Ito M, Fukuyama R, Miyazaki T, Kitaura H, Nakamura K, Fujita T, Kanatani N, Moriishi T, Yamana K, Liu W, Kawaguchi H, Nakamura K, Komori T (2007) Runx2 determines bone maturity and turnover rate in postnatal bone development and is involved in bone loss in estrogen deficiency. Dev Dyn 236: 1876-1890.
Mornet E (2007) Hypophosphatasia. Orphanet J Rare Dis 2: 40 .

Nefussi JR, Brami G, Modrowski D, Oboeuf M, Forest N (1997) Sequential expression of bone matrix proteins during rat calvaria osteoblast differentiation and bone nodule formation in vitro. J Histochem Cytochem 45: 493503.

Stein GS, Lian JB, van Wijnen AJ, Stein JL, Montecino M, Javed A, Zaidi SK, Young DW, Choi JY, Pockwinse SM (2004) Runx2 control of organization, assembly and activity of the regulatory machinery for skeletal gene expression. Oncogene 23: 4315-4329.

Tsigkou O, Jones JR, Polak JM, Stevens MM (2009) Differentiation of fetal osteoblasts and formation of mineralized bone nodules by $45 \mathrm{~S} 5$ Bioglass conditioned medium in the absence of osteogenic supplements. Biomaterials 30: 3542-3550.

Wennberg C, Hessle L, Lundberg P, Mauro S, Narisawa S, Lerner UH, Millán JL (2000) Functional characterization of osteoblasts and osteoclasts from alkaline phosphatase knockout mice. J Bone Miner Res 15: 1879-1888. 